\title{
PAI-1, the Plasminogen System, and Skeletal Muscle
}

\author{
Fasih Ahmad Rahman ${ }^{1}$ and Matthew Paul Krause ${ }^{2, *}$ \\ 1 Department of Kinesiology, University of Waterloo, Waterloo, ON N2L 3G5, Canada; \\ fasih.rahman@uwaterloo.ca \\ 2 Department of Kinesiology, University of Windsor, Windsor, ON N9B 3P4, Canada \\ * Correspondence: mpkrause@uwindsor.ca; Tel.: +1-519-253-3000 (ext. 2443)
}

Received: 28 August 2020; Accepted: 23 September 2020; Published: 25 September 2020

\begin{abstract}
The plasminogen system is a critical proteolytic system responsible for the remodeling of the extracellular matrix (ECM). The master regulator of the plasminogen system, plasminogen activator inhibitor-1 (PAI-1), has been implicated for its role in exacerbating various disease states not only through the accumulation of ECM (i.e., fibrosis) but also its role in altering cell fate/behaviour. Examination of PAI-1 has extended through various tissues and cell-types with recent investigations showing its presence in skeletal muscle. In skeletal muscle, the role of this protein has been implicated throughout the regeneration process, and in skeletal muscle pathologies (muscular dystrophy, diabetes, and aging-driven pathology). Needless to say, the complete function of this protein in skeletal muscle has yet to be fully elucidated. Given the importance of skeletal muscle in maintaining overall health and quality of life, it is critical to understand the alterations-particularly in PAI-1-that occur to negatively impact this organ. Thus, we provide a comprehensive review of the importance of PAI-1 in skeletal muscle health and function. We aim to shed light on the relevance of this protein in skeletal muscle and propose potential therapeutic approaches to aid in the maintenance of skeletal muscle health.
\end{abstract}

Keywords: plasminogen activator inhibitor-1; plasminogen system; skeletal muscle; pathophysiology; regeneration; muscular dystrophy; diabetes; aging; exercise; therapeutics

\section{Introduction}

The plasminogen system is a proteolytic system responsible for the degradation of several proteins, most notably, fibrin. The initial study identifying key features of this process particularly during the dissolution of blood clots was first published in 1893 by a French physiologist named Albert Dastre [1]. Dastre coined the term "fibrinolysis" and it was not until the mid-twentieth century where major aspects of this process were revealed, including the identification of the circulating latent zymogen, plasminogen, and its active form, plasmin [1-7]. A role for the plasminogen system in modulating extracellular matrix (ECM) structure has since been identified in several tissues. Plasmin is capable of directly degrading fibrin or activating downstream proteases to degrade structural proteins of the ECM. Plasminogen is activated by plasminogen activators (PAs): tissue-type PA (tPA) and urokinase-type PA (uPA). It was not until the 1980s when the major regulator of the plasminogen system, plasminogen activator inhibitor-1 (PAI-1), was identified [8,9]. PAI-1 tightly regulates the activity of tPA and uPA and as a result prevents a constant state of fibrinolysis $[8,9]$. Perhaps reflecting the diversity of biological roles played by PAI-1, including regulation of cell death [10,11], senescence [12,13], and inflammation [14,15], PAI-1 has been identified as a bona fide marker in several pathological conditions. Given that PAI-1 is present within the circulation under normal and pathological conditions, it is unsurprising that this protein is capable of affecting virtually all tissues/organs in the body. For instance, high levels of PAI-1 have been implicated in cancer [16-20], cardiovascular disease [21-23], diabetic complications [23,24], 
renal disease [25,26], musculoskeletal disorders [27-30], and tissue fibrosis [31-33]. In skeletal muscle, PAI-1 plays critical roles in response to skeletal muscle injury and in myopathic conditions [27-29,34,35], further highlighting the importance of the plasminogen system and ECM remodeling to skeletal muscle. Indeed, several studies have identified the importance of plasminogen system function but have yet to fully elucidate a role for PAI-1 in skeletal muscle [35-40], although recent evidence suggests that skeletal muscle is also a site of PAI-1 synthesis [29,41,42]. Control of PAI-1 levels in the circulation is of clinical importance and while studies generally indicate that circulating PAI- 1 can be controlled with exercise [43-60] or through the administration of pharmacological PAI-1 inhibitors [17,22,61-71]. This review will summarize the biology of PAI-1 and the plasminogen system as it relates to overall tissue function and ECM remodeling, highlight the role of PAI-1 in skeletal muscle, and shed light on potential therapeutic strategies to reduce or normalize PAI-1 levels in an attempt to improve muscle and overall health.

\section{Basic Biology of PAI-1 and the Plasminogen System}

\subsection{Structure and Function of PAI-1}

PAI-1 is secreted as a single chain molecule that contains two distinct interactive domains; (1) a reactive center loop (RCL), (2) a flexible joint region with helix $\mathrm{D}(\mathrm{hD})$, helix $\mathrm{E}(\mathrm{hE})$, and helix $\mathrm{F}(\mathrm{hF})$ binding sites (Figure 2A) [16]. The RCL domain is the primary site for UPA/tPA binding and contains a $\mathrm{P} 1-\mathrm{P} 1^{\prime}$ peptide bond that interacts with these proteases. Upon cleavage of the P1-P1' bond, PAI-1/PA molecules form an irreversible complex resulting in the inactivation of PA, and partial internalization of the RCL domain (Figure 2B) [72-74]. uPA and tPA may also cleave PAI-1 without forming an irreversible complex [75]. In this instance, PAI-1 is still capable of interacting with other proteins with its helix domains, but its ability to inhibit uPA/tPA is abolished [75].

Binding of the flexible domain of PAI- $1(\mathrm{hD}, \mathrm{hE}$, and $\mathrm{hF}$ sites) to vitronectin prevents adjacent binding of vitronectin with integrin and stabilizes PAI- 1 in its active form while increasing its binding affinity with uPA/tPA 200-fold (Figure 1F) [76-78]. Furthermore, PAI-1 can detach cells through the interaction with uPA bound to its receptor (UPAR). In the absence of PAI-1, uPA bound to uPAR results in a conformational change that increases uPAR affinity for vitronectin or other integrins, and thus, maintain cell adhesion [79-82]. However, PAI-1 binding to uPA-uPAR can disrupt this interaction with vitronectin or integrin, reducing adhesion/migration of cells (Figure 2F) [79-84]. PAI-1 may also interact directly with the somatomedin B domain on vitronectin with greater affinity than UPAR, thus, further diminishing cell adhesion [85]. Furthermore, PAI-1 bound to the uPA-uPAR complex can interact with lipoprotein receptor-related protein 1 (LRP1) found on the cell membrane via its $\mathrm{hD}$ and $\mathrm{hE}$ domains, and trigger endocytosis of the UPAR complex; resulting in reduced levels of uPA and uPAR (Figure 1G) [76,86]. Together, the lack of uPA/uPAR activity, and diminished cell adhesion and migration may potentiate apoptosis of cells [87].

Thorough assessment of PAI-1 structure has also revealed that this protein is secreted from cells in its active form, however this form is short lived. The typical half-life of active PAI- 1 is between $1-2 \mathrm{~h}$ before it is spontaneously converted to its highly stable latent (partially inactive) form [88-91]. Similar to the cleavage of the P1-P1' peptide bond by plasminogen activators resulting in internalization of the RCL domain (Figure 1D), this phenomenon can occur spontaneously without the cleavage of the $\mathrm{P} 1-\mathrm{P} 1$ ' bond, and this conformation may serve as a regulatory mechanism to prevent prolonged anti-fibrinolytic action of PAI-1 [75]. Nonetheless, the latent form can be reactivated by denaturing and refolding, although this event may not be physiologically relevant [92,93]. Similar to the cleaved form of PAI-1, latent PAI-1 can interact with cell surface receptors or ECM molecules via its helix domains or it may bind directly to fibrin as a result of this new conformation to inhibit tPA-induced degradation (Figure 1D,F) [94]. 


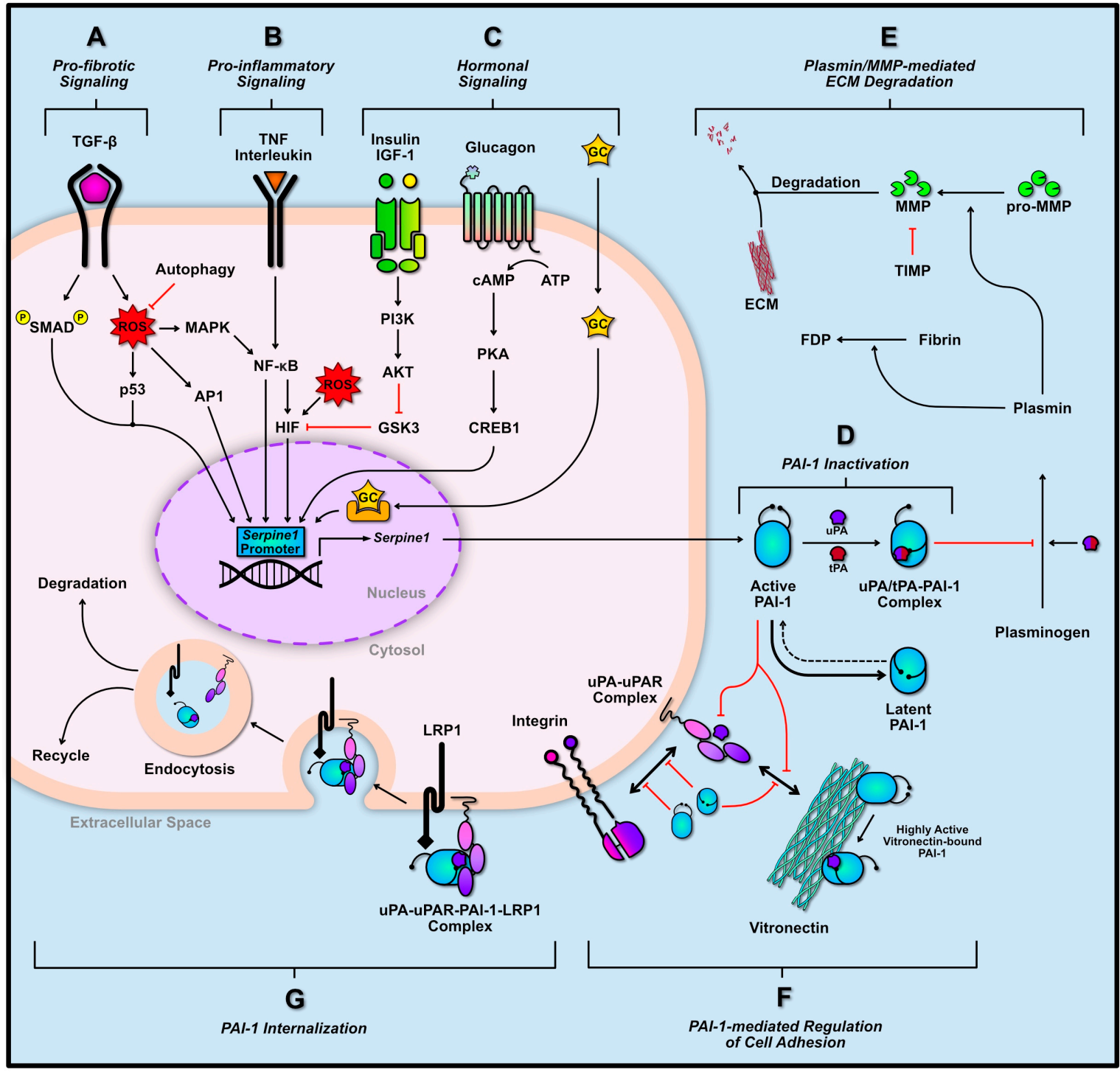

Figure 1. Serpine1 transcriptional regulation and PAI-1 function. Serpine1 can be transcribed through several signaling cascades including pro-fibrogenic (A), pro-inflammatory (B), and pro-growth/hormonal signaling cascades (C). Once transcribed, PAI- 1 is secreted in its active form into the extracellular space where it can inhibit urokinase-type PA (uPA)/tissue-type PA (tPA), and thus inhibit downstream extracellular matrix (ECM) degradation by preventing matrix metalloproteinase (MMP) activation (D,E). Conversely, PAI-1 may be rapidly converted to its more stable latent state. The active and latent PAI-1 molecules can interact with uPA/uPA receptor (uPAR) and integrins to diminish cell adhesion to vitronectin (F). Vitronectin-bound PAI-1 prevents its premature conversion to its latent state and improves its binding affinity to uPA/tPA. PAI-1 may also be internalized by the cell, through its interaction with lipoprotein receptor-related protein 1 (LRP1) and UPA/uPAR, ultimately leading to its degradation or recycling (G). Solid black arrows indicate activation. Dotted black lines indicate potential yet unfavorable pathways. Red bars indicate inhibition or blockage. Two-way arrows indicate interaction between proteins. 
As the master regulator of the plasminogen system, PAI-1 plays an important role in ECM remodeling through the modulation of matrix metalloproteinase (MMP) activity. Although PAI-1 does not interact with MMP directly, its upstream inhibitory role on plasmin activation diminishes the cleavage-mediated activation of pro-MMP (Figure 1E) [32,95]. Interestingly, plasmin is also capable of inducing increased MMP secretion whereas its zymogen (i.e., plasminogen) can induce increased secretion of PAI-1 [95]. The induction of PAI-1 in this manner may serve as a negative-feedback mechanism to limit plasmin- and MMP-mediated ECM degradation [95]. Tissue inhibitors of metalloproteinases (TIMP)s are typically expressed concurrently with PAI-1 [96-99]. For example, fibrogenic signaling cascades tend to increase levels of PAI-1 and TIMPs together [98-100]. TIMPs directly inhibit MMPs, thereby blocking ECM degradation.

A

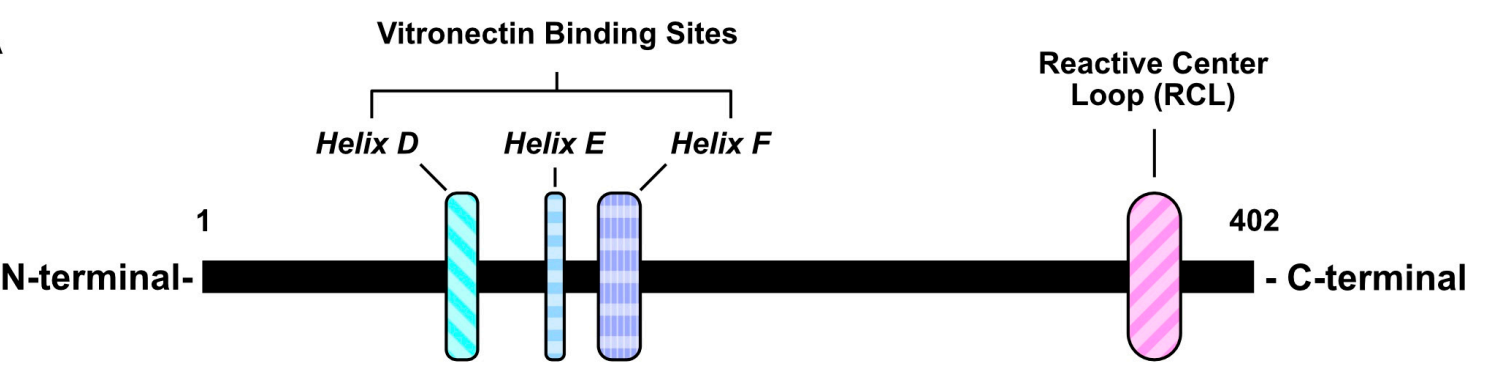

B

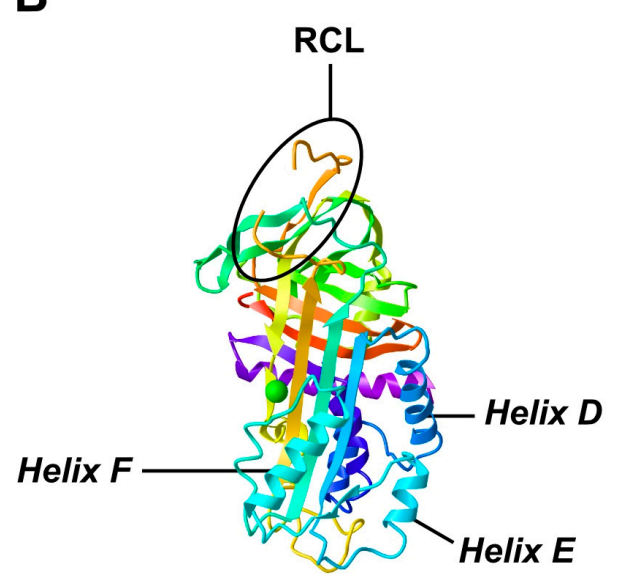

Active Conformation

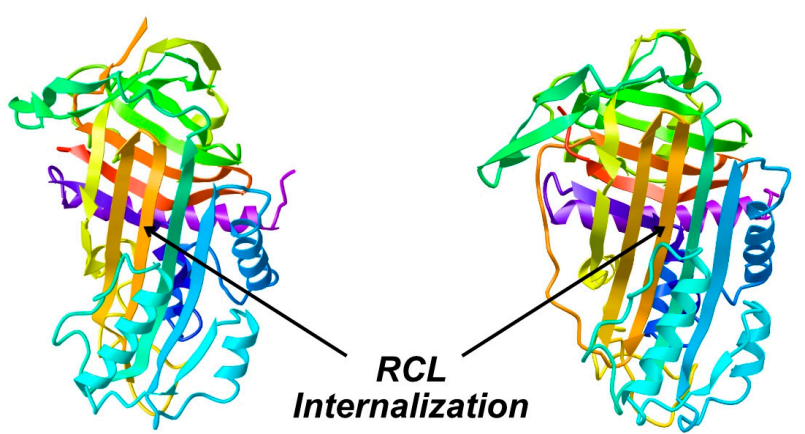

Cleaved Conformation

\section{Latent}

Conformation

Figure 2. Illustration of plasminogen activator inhibitor-1 (PAI-1) linear (A) and crystalline (B) structure. Crystalline structure adapted from [101,102].

\subsection{Transcriptional Regulation of PAI-1}

PAI-1 is rapidly synthesized and secreted in response to multiple signaling cascades. The transcriptional regulation of which has been largely investigated. PAI-1 is expressed in vasculature (endothelial and smooth muscle cells), immune cells, heart, liver, kidney, adipose tissue, as well as some cancer cell types $[18,20,103]$. Skeletal muscle also appears to express PAI-1, at least during regeneration, suggesting that PAI-1 plays a role in modulating skeletal muscle ECM [29,41,42] (GEO dataset: GDS234; Reference series GSE469). Regardless of tissue origin, the transduction of Serpine1 (i.e., gene encoding for PAI-1) remains similar across most if not all tissue types. This section will highlight the major contributors to Serpine1 transduction in three categories: (1) pro-fibrotic signaling, (2) pro-inflammatory signaling, and (3) hormonal signaling (Figure 1A-C). 
The pro-fibrotic signaling of transforming growth factor- $\beta$ (TGF- $\beta$ ) is a major contributor to PAI- 1 transduction (Figure 1A). The canonical activation of TGF- $\beta$ signaling occurs through the binding of TGF- $\beta$ to its receptor resulting in the phosphorylation and activation of SMAD2/3. Activated SMAD2/3 can associate with SMAD4 and translocate to the nucleus and bind to the Serpine1 promoter, along with other pro-fibrotic promoter regions $[104,105]$. The TGF- $\beta$ cascade has multiple non-canonical pathways as well. These include the elevation of mitochondrial and cytosolic reactive oxygen species (ROS), resulting in the subsequent activation of mitogen-associated protein kinase (MAPK), and nuclear factor kappa B (NF-kB) [106-109]. In fact, the production of ROS is thought to be a major mediator of TGF- $\beta$-mediated Serpine1 transcription [110]. Elevations in ROS also signal the transduction of cell cycle regulator p53, which alongside SMAD2/3/4, can aid in the transcription of Serpine1 [111,112]. ROS signaling can also stimulate activator protein-1 (AP-1), and hypoxia-inducing factor-1 $\alpha(\mathrm{HIF}-1 \alpha)$ [113-115]. In addition to its regulation of Serpine1, TGF- $\beta$ signaling has been shown to increase the half-life of Serpine1 mRNA, thereby increasing PAI-1 protein translation [116].

Serpine 1 expression can also be induced in response to characteristic inflammatory signaling including tumor necrosis factors (TNF) and interleukins (IL) (Figure 1B). Binding of TNF to its respective receptor can lead to the direct activation of NF-KB, and subsequent Serpine1 transcription [117-119]. Furthermore, the inhibition of $\mathrm{TNF} \alpha$ via adiponectin has also been shown to reduce Serpine1 expression [120]. IL-signaling demonstrate similar transduction of Serpine1 to that of TNF. Binding of IL receptors can directly activate NF-KB (e.g., IL-1R), or elevate MAPK levels (e.g., IL-6R) within cells, once again leading to the transcription of Serpine1 [117,121,122].

Several hormones influence Serpine1 transcription, including insulin, glucagon, and glucocorticoids (GC) (Figure 1C). Both proinsulin, insulin, and insulin-like growth factor-1 (IGF-1) have been shown to induce Serpine1 expression $[117,123]$. This was found to be a result of activation AKT, leading to the inhibition of glycogen synthase kinase-3 (GSK3) [117]. Inactivation of GSK3 prevents the inhibitory phosphorylation of HIF, enabling it to translocate to the nucleus and transcribe Serpine1 [117]. Binding of glucagon to its $G$ protein coupled receptor stimulates adenylate cyclase and leads to elevated cytosolic concentration of cyclic AMP (cAMP), subsequently activating protein kinase A (PKA). Activated PKA can phosphorylate cAMP-response element binding protein-1 (CREB1), which can translocate to the nucleus and transcribe Serpine1 [124]. Finally, the translocation of lipid soluble GC into the nucleus and their interaction with nuclear receptors can also mediate Serpine1 transcription [124].

\section{Role of PAI-1 Following Skeletal Muscle Damage}

Skeletal muscle is an organ that displays high plasticity in response to damage and is able to repair or regenerate its architecture within a relatively short time span (approx. 10 days) and return it to normal function. Given that contractile events can cause tremendous stress in skeletal muscle, coupled with the fact that physical trauma can severely hinder muscle function, it is critical to understand the nuances of the regeneration process. The regeneration of skeletal muscle can be broadly categorized into three phases: (1) the degeneration and inflammation phase, (2) regenerative myogenesis of muscle stem cell (i.e., satellite cells), and (3) remodeling of the ECM (Figure 3). Each of these phases is characterized by the distinct involvement of multiple cell types, yet there is considerable overlap. For instance, remodeling of the ECM occurs as early as the onset of the degeneration and inflammation phase. Similarly, as the inflammatory phase subsides, myogenesis begins to ramp up. In essence, the balance of the antagonistic roles of PAI- 1 and uPA have been implicated during all phases of the regeneration process. Albeit, the intricacies of PAI-1 during skeletal muscle regeneration has yet to be fully elucidated, the known function of PAI- 1 and other effectors of the plasminogen system on skeletal muscle regeneration will be highlighted in this section. 


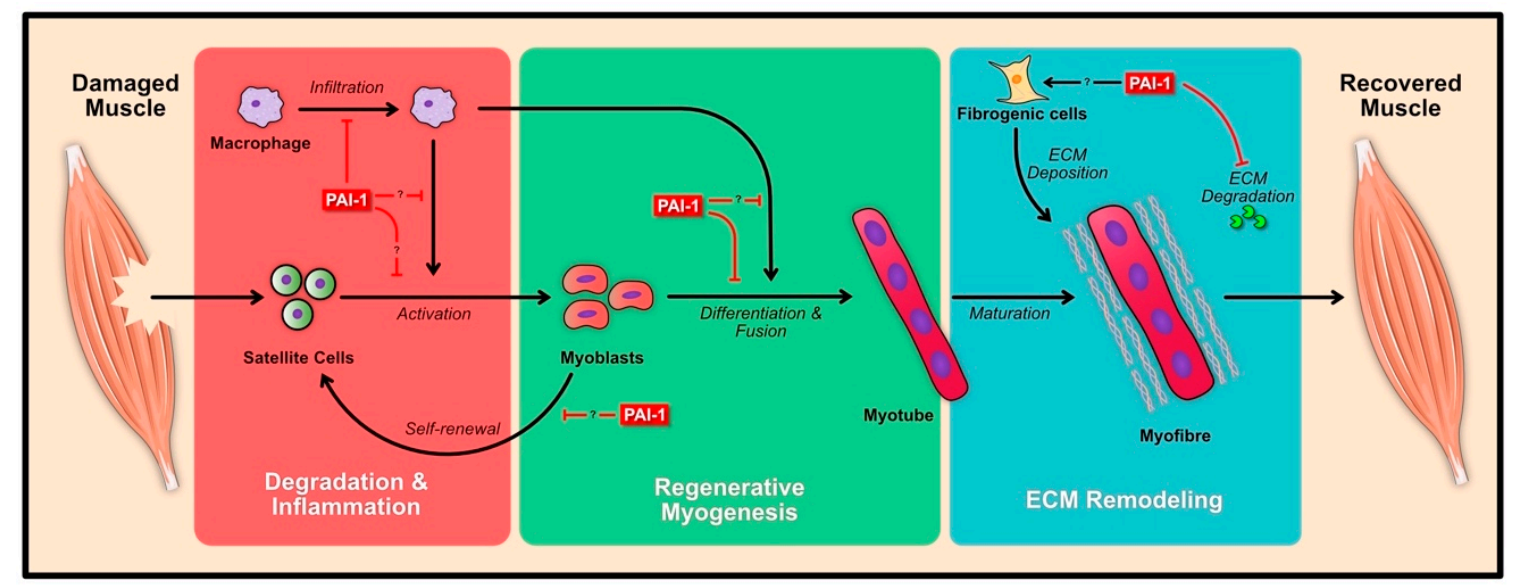

Figure 3. Effects of PAI-1 during skeletal muscle regeneration. Induction of muscle damage results in the swift infiltration of immune cells (macrophages shown), resulting in the degradation of cellular debris and activation of satellite cells to form myoblasts. The activated myoblasts differentiate and fuse to form myotubes, which then mature within their niche to form complete myofibres. PAI- 1 has been shown to inhibit the regeneration process at various levels (red bar lines), however the role of PAI-1 relating to satellite cell, myoblast and other cells (immune and fibrogenic cells) during regeneration has yet to be explored. Solid black arrows indicate activation. Red bars indicate inhibition or blockage.

\subsection{Degeneration and Inflammation}

Once damaged, skeletal muscle begins to efficiently orchestrate its regenerative response. The first phase involves the degradation of cellular debris and inflammation accompanied by immune cells. Neutrophils are the among the first to arrive at the site of damage within $24 \mathrm{~h}$ and begin to degrade debris through phagocytosis [125]. Neutrophils also release chemotactic signals to attract highly important monocytes. Unlike neutrophils, monocytes or macrophages are essential for regeneration, the lack or aberrant expression of this cell type has been shown to impair the regenerative response in muscle. Infiltrated monocytes can differentiate to classical M1 macrophage and take over the bulk degradation of cellular debris. Afterwards, these cells may further differentiate into alternative M2 macrophages, releasing anti-inflammatory signals that ease the degradation of tissue and signal for its reconstruction.

The generalized role of the plasminogen system has been shown to be important during skeletal muscle regeneration with multiple proteins playing a part in this coordinated response. For instance, the knockout (KO) of Plg (i.e., gene encoding for plasminogen) has been shown to severely impair regeneration after glycerol-induced muscle damage [37]. It was shown that in Plg KO muscle, the infiltration of neutrophils and macrophages was diminished 2 days post injury [37]. However, macrophage infiltration and regeneration were rescued in these $\mathrm{KO}$ animals through the systemic treatment of fibrinogenolytic agent, ancrod [37]. It was also noted that plasminogen activation was highly dependent upon uPA activity but not tPA [37]. Thus, both plasmin and uPA are essential for muscle regeneration.

Following cardiotoxin (CTX)-induced muscle damage, the activity of uPA and tPA increases; with a greater magnitude of increase in uPA [28]. In Serpine1 KO animals, uPA levels were elevated from 1 day and remained elevated up to 5 days post-CTX [28]. Interestingly, when investigating muscle force production and presence of necrotic area, Serpine1 $\mathrm{KO}$ animal were found to recovery muscle strength (i.e., force), and demonstrated rapid necrotic area clearance compared to wild-type (WT) animals [28]. Furthermore, muscle force and regeneration were significantly impaired in Plau (i.e., gene encoding for uPA) $\mathrm{KO}$ animals, suggesting that uPA activity is needed for regeneration and PAI-1 impairs regeneration. Plau KO but not Plaur (i.e., gene encoding for uPA receptor) KO animals also displayed impaired macrophage infiltration while neutrophil infiltration remained unchanged [28,126]. Furthermore, macrophage-specific secretion of uPA was found to be important 
in muscle regeneration by modulating fibrin degradation, and promotion of ECM breakdown [127]. In contrast, Serpine1 KO animals were found to have elevated macrophage numbers from 3 days to 5 days post-CTX [28]. Together these data suggest that unbound/soluble uPA activity is needed for muscle regeneration, and PAI-1 can negatively impact its role in regeneration. In fact, in diabetic and aged muscle, where PAI-1 levels are elevated, aberrant macrophage infiltration has also been observed [27,29]. Interestingly, however, the chemical inhibition of PAI-1 by tiplaxtinin (PAI-039) was found to rescue early impairments in regeneration in diabetic muscle, particularly in the necrotic regions, and likely by facilitating macrophage infiltration [27,128]. It is unclear whether muscle tissue PAI-1 levels interfere with the function of infiltrated macrophages, specifically in their ability to activate muscle stem cells.

\subsection{Regenerative Myogenesis}

Indeed, the involvement of immune cells, namely macrophages, is important in initiating skeletal muscle regeneration. However, the cells that are central for the regeneration of muscle fibres are satellite cells. Upon activation, satellite cells undergo a several rounds of division, migrate to the site of damage, differentiate to form myotubes, and fuse together to form new muscle fibres [129,130]. The differential expression of myogenic regulatory factors (MRFs) is essential for the progression of satellite cells to form de novo myofibres. Myogenic determination protein 1 (MYOD1), and myogenin (MYOG) are among the two important factors that have been associated with several functions during the regeneration process. Naturally, an impairment in any of these key events or aberrant expression of these MRFs during myogenesis results in impaired muscle regeneration; and this is often accompanied by fibrosis.

The aforementioned studies $[126,128,131]$ have also briefly investigated PAI- 1 on satellite cell function. Serpine1 KO animals were found to induce greater MYOD1 levels, embryonic myosin heavy chain content, and centrally located nuclei; indicating increased regeneration [28]. Interestingly, Serpine1 $\mathrm{KO}$ animals were able to regenerate muscle at a higher rate compared to WT [28]. A similar finding was observed in diabetic muscle, where the chemical inhibition of PAI-1 was found to improve satellite cell activation in the necrotic regions [128]. This mechanism of this phenomena was proposed to be a result of the activity of the downstream matrix metalloproteinase-9 (MMP-9), likely originating from macrophages $[29,127,128]$. Studies have also demonstrated that active uPA and its function to cleave plasminogen to form plasmin is required for myoblast differentiation and myotube formation $[37,38,40]$. Thus, the impairment in uPA activity or the $\mathrm{KO}$ of Plg entirely has negative consequences on myogenesis. Contrary to these findings, a recent study has shown that PAI-1 may not affect myoblast differentiation per se, rather PAI-1 may impair development of fused myotubes. This study showed that the administration of PAI-1 (i.e., gain of function) or the knockdown of Serpine1 using siRNA had no effect on protein synthesis/AKT signaling, nor did it affect differentiation markers (MYOD1, MYOG, and myosin) [132]. Instead, PAI-1 was found to reduce IGF-1 protein levels (a critical growth factor) within muscle [132], however, further investigation is needed as to whether PAI-1 is associated with morphological changes (length, width, number of nuclei, etc.) of newly formed myotubes.

The role of uPA/PAI-1 balance in mediating cell migration has also been studied in myoblasts. In most instances, the activators of PAI- 1 have also been demonstrated to reduce Plau mRNA expression. For example, IL-17 treatment of C2C12 myoblasts and subsequent MAPK14 activation was found to reduce Plau mRNA and protein expression in a dose dependent manner [121]. In other words, high levels of interleukin-mediated stress signaling in myoblasts suppresses Plau expression, and thus impairs fibrinolysis. Both PAI- 1 and IL-17 treated cells displayed reduced differentiation and migration in a similar manner [121]. Direct chemical inhibition of uPA activity has also been shown to reduce primary and $\mathrm{C} 2 \mathrm{C} 12$ myoblast migration, however, uPAR was found to be dispensable during myogenesis [121,133]. Impaired myoblast migration in Plau deficient or PAI-1 treated cells is consistent with in vivo findings demonstrating poor macrophage infiltration $[28,29,128]$. It may be possible that 
the muscle tissue-specific PAI-1 levels are limiting cell migration, and thus, leading to poor regeneration. Additionally, the effect of PAI-1 on satellite cell self-renewal has yet to be investigated.

\subsection{ECM Remodeling}

The remodeling of the ECM occurs at every stage of the regeneration process but varies in its magnitude. ECM plasticity is required for the infiltration of immune cells during the early stages of the degeneration/inflammation phase. ECM turnover is also required for the migration of satellite cells and formation of new scaffolding material for the newly formed myotubes to situate themselves within. Indeed, the inhibitory effect of PAI-1 on plasminogen activation plays an important role in ECM remodeling during regeneration, however, the effect of the downstream proteases of the plasminogen system should not be dismissed. Moreover, the genetic ablation or inhibition of plasmin, uPA, and matrix metalloproteinases (MMPs) impairs muscle regeneration.

Several members of the MMP family have been shown to be involved in the remodeling of muscle following damage. MMP-2 and MMP-9, two gelatinases, are among the best characterized. MMP-2 is constitutively expressed in muscle whereas MMP-9 is induced as early as 1 day following CTX-injury $[134,135]$. The secretion and activity of MMP-9 early during the regeneration process necessitates the need to remove excess ECM material to enable efficient immune cell infiltration into the damage regions $[27,29,134,136,137]$. Further investigations of MMP-9 have elucidated its colocalization with macrophages early in the regeneration process [29]. In diabetic plasma and aged muscles, where PAI-1 levels are elevated, reduced MMP-9 levels are observed, and they coincide with ECM accumulation, poor satellite cell activation and muscle regeneration $[29,128,134]$. Under these conditions, PAI-1 is likely inhibiting the activation of MMPs through the inhibition of uPA and plasmin. PAI-1 may also be interacting with fibrogenic cells within the damaged tissue to exacerbate ECM deposition.

C2C12 cells have been established to migrate at a faster rate than primary myoblasts [138]. In the presence of MMP inhibitors, C2C12 migration is diminished after transplantation [138]. In vitro experiments have shown that $\mathrm{C} 2 \mathrm{C} 12$ cells fail to express MMP-9 but differentially express MMP-2 during differentiation and is needed for migration [134,138,139]. Activation of MMP-2 via membrane type-I MMP (MT1-MMP) and overexpression of Mmp2 in myoblasts was found to increase primary myoblast migration [138]. Transplantation of C2C12 cells alongside MMP-1 was also found to improve graft efficiency and muscle regeneration through the remodeling of the ECM [140-142]. Considering the active involvement of MMPs in grafting success, it is likely that the selective targeting and transient inhibition of PAI-1 during skeletal muscle grafting would improve engraftment success. Nonetheless, MMP-13 has also been shown to increase throughout the regeneration process and aid in the migration of satellite cells [135]. Surprisingly, MMP-13 overexpression was found to increase MYOG levels in C2C12 cells, yet it did not impact myoblast fusion and is dispensable in resting muscle $[135,143]$.

As myoblasts/satellite cells progress through into the final stages myogenesis-differentiation and fusion — the level of MMPs typically drops and the expression of TIMPs increases [136,139]. Myoblasts typically do not express TIMP during the early stages of differentiation-likely to maximize MMP activity. In fact, the genetic overexpression of Timp 2 in myoblasts prevents myotube formation, whereas the gradual increase in TIMP-1 in myotubes is associated with their maturation [136,139]. Interestingly, the lack of colocalization of TIMP-2 and MMPs in C2C12 myoblasts may suggest the alternative role (i.e., non-ECM-related roles) of these proteins during differentiation [139]; however, this has yet to be fully elucidated. 


\section{Pathological Role of PAI-1 in Skeletal Muscle}

\subsection{Muscular Dystrophy}

Muscular dystrophy is a class of disease that leads to progressive muscle loss and weakness. Duchenne muscle dystrophy (DMD) is one of the most common forms of X-linked lethal diseases, known to affect almost 1 in 3000 males [144]. This disease originates from a mutation in the gene encoding for the cytoskeletal anchoring protein, dystrophin, resulting in severe alterations in cytoskeletal structure and impaired muscle morphology. This devastating disease remains incurable, with multiple therapeutic approaches being heavily investigated. Nonetheless, in most instances, this disease is accompanied by prolonged inflammation and fibrosis (Figure 4). Given the role of PAI-1 in modulating the plasminogen system, and thus regulating fibrosis, numerous studies have investigated its role in DMD.

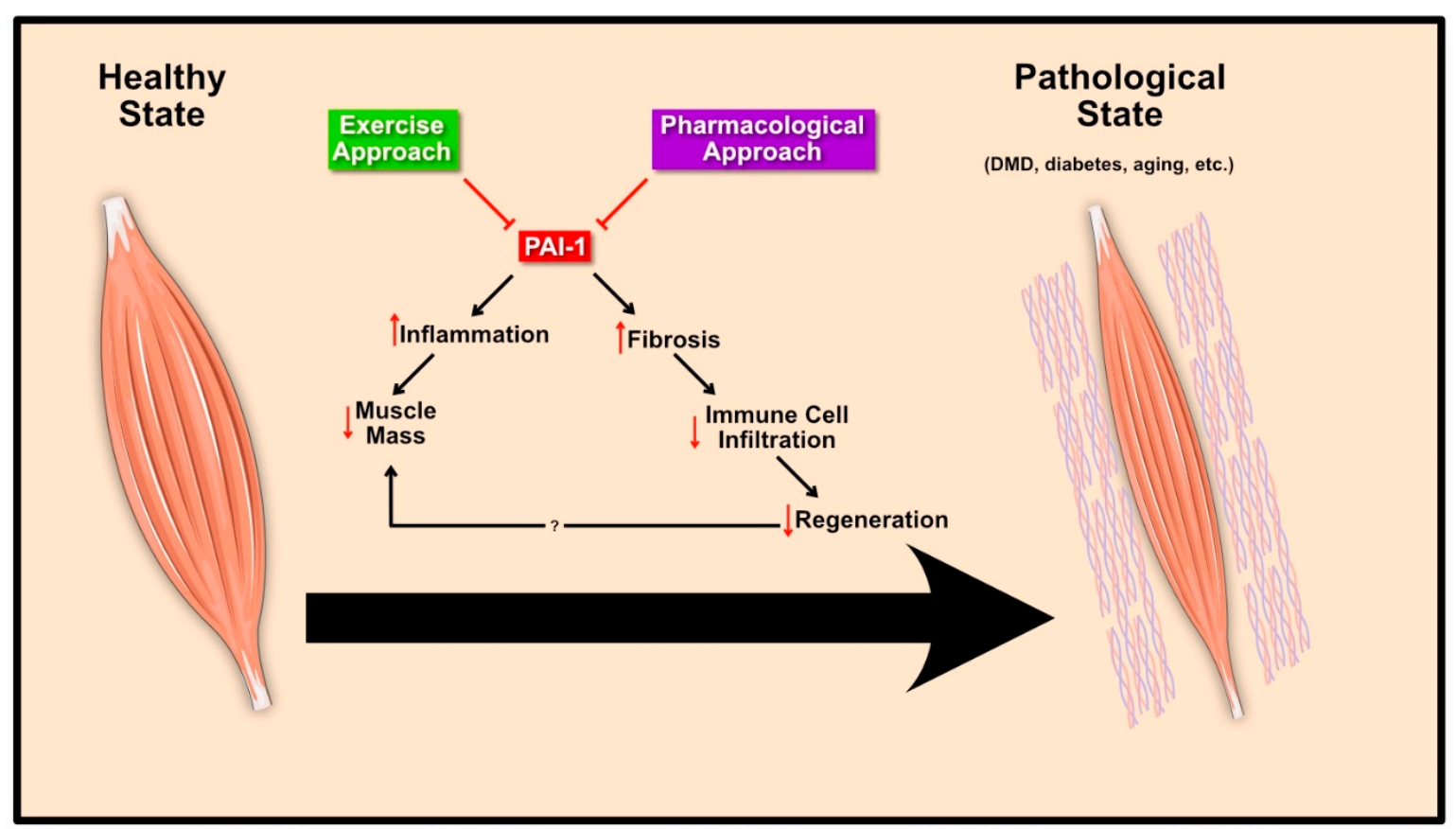

Figure 4. PAI-1 in muscle pathology and therapeutics. Excessive PAI-1 levels lead to increased fibrosis and are associated with inflammation. In skeletal muscle, this results in impaired regeneration and reduced muscle mass in various pathological states. Exercise and pharmacological agents reduce circulating PAI-1 levels and serve as a therapeutic approach to normalize PAI-1 levels and improve skeletal muscle health.

Although PAI-1 is not the primary cause of muscular dystrophy, its atypical expression in resting dystrophic muscle provides some insight into its role. Most studies investigating DMD utilize the $m d x$ mouse model. Serpine1 expression has been shown to dramatically increase in the first 4 months of life in $m d x$ mice and begin to decline afterwards [34]. The rapid increase in Serpine1 is also accompanied by elevations in collagen deposition during early development. Interestingly, fully developed Serpine1 KO $m d x$ animals demonstrated greater fibrosis as a result of increased TGF- $\beta / S M A D$ signaling, elevated TIMP-1 and Type-I collagen [34]. This was proposed to be a result of excessive elevations in uPA, resulting in the conversion of latent to active TGF- $\beta$, and was rescued through the inhibition of uPA. In other words, PAI-1 induced moderate fibrosis as a protective mechanism to reduce the conversion of latent TGF- $\beta$. 
To complicate matters further, previous work from the same group has shown that $u P A K O$ in $m d x$ mice has negative consequences particularly as the animals age (i.e., from youth to adulthood), resulting in functionally impaired and chronically degenerating muscle fibres [35]. The lack of uPA reduces the infiltration of immune cells that is needed to clear the degenerating myofibres. To demonstrate the importance of uPA in $m d x$ muscle, uPA-derived from bone marrow transplants or the treatment of $m d x$ muscle with Ancrod (a fibrinolytic agent) were both shown to promote immune cell infiltration alleviate the chronic degradation of myofibres [35]. In fact, bone marrow transplant experiments were shown to improve the dystrophic phenotype through multiple uPA-dependent mechanisms [35]. Additionally, in vitro studies have shown that PAI-1 and UPAR levels are elevated in primary satellite cells derived from $m d x$ muscle [39,145], whereas the aforementioned study suggests otherwise [35]. Nonetheless, the in vitro role of uPA-uPAR-PAI-1 has been implicated for their importance in $m d x$ satellite cell survival and migration $[39,145]$. Together, these data hint at the importance of uPA/uPAR/PAI-1 balance in dystrophic muscle. Imbalances in either of these proteins have negative consequences and exacerbate the dystrophic phenotype and accompanied fibrosis.

\subsection{Diabetes Mellitus}

Diabetes is a disease classified by chronic and abnormal elevation in blood glucose levels. Diabetes affects individuals of all ages and can either be autoimmune (Type 1) or lifestyle-dependent (Type 2). Regardless of the origin, diabetes leads to negative changes to virtually every organ within that body. At the muscle level, diabetes leads to several pathological changes, collectively termed diabetic myopathy, including impaired metabolic capacity, muscle atrophy, reduced capillarization, accumulation of intramyocellular lipids, impaired muscle progenitor cell responses, and elevations in pro-inflammatory markers including PAI-1 [128,146-149]. Although PAI-1 is a transcriptional target of insulin signaling in multiple tissue/cell types, PAI-1 expression is elevated in Type 1 and 2 diabetes $[24,150,151]$ and in diabetic animal models with no insulin treatment [146]. However, the impact of elevated PAI-1 in diabetes on skeletal muscle health is not well understood. Elevated plasma PAI-1, irrespective of its origin, has been shown to impair the muscle microenvironment, particularly following injury leading to impaired regeneration $[27,128]$ (Figure 4). Most notable from these findings is the fact systemic PAI-1 affected macrophage and satellite cell function following muscle injury [128] and that pharmacologic inhibition of PAI-1 at least partly restores regenerative capacity of both muscle [27] and skin [152]. Future work in this field is highly warranted given the interplay between PAI-1 and skeletal muscle (or other tissues) in diabetic conditions.

\subsection{Aging}

Aging can be characterized by the progressive deterioration of multiple organs and organ systems, leading to mortality. It can be argued that biological aging is a major culprit leading to the development of various diseases. However, it should be noted that aging encompasses multiple hallmarks including genomic instability and loss of proteostasis, resulting in senescence, metabolic dysfunction, altered stem cell function, and other perturbations [153]. These hallmarks have also been associated with PAI-1 expression in numerous age-related diseases [12,32,154]. The role of PAI- 1 in aging muscle, however, is largely unknown. Recent work has shown that aged muscle expresses greater levels of PAI-1 following injury [29] (GEO dataset: GDS234; Reference series GSE469), however, it is unclear why this is the case. Aging is associated with elevations in pro-fibrotic, pro-inflammatory, or pro-growth (insulin, IGF-1, etc.) signaling, coupled with oxidative stress that may contribute to elevated PAI-1, yet these findings have not been investigated in aged muscle (Figure 4). It would be of interest to know if aged muscle is a major source of PAI-1 or whether muscle-specific Serpine1 KO would improve systemic aging. Thus, further investigation of PAI-1 in aging muscle may unravel important features of this protein in maintaining whole-body homeostasis. 


\section{Therapeutic Interventions to Normalize PAI-1}

The investigation of PAI-1 is relevant for clinical application to various disease states [16-33]. PAI-1 levels are elevated in several diseases states and, in rodent models, the ablation/inhibition of PAI-1 tissue repair $[27,28,126,132]$ whereas deficiency in Plau or other components of the plasminogen system has the opposite effect $[28,35,37,38,40]$. Interestingly, PAI-1 deficiency seems to prolong the lifespan, as demonstrated in transgenic Klotho mice (a model of premature aging) [155], yet the chemical inhibition of PAI-1 does not alter lifespan [156]. Although the clinical goal would be to control PAI-1 activity, PAI-1 deficiency may carry negative consequences. Mutation in human SERPINE1 is a known cause of a rare bleeding disorder due to poor blood clotting $[157,158]$. Conversely, heterozygous carriers of a null SERPINE1 mutation was associated with reduced prevalence of diabetes and an extended lifespan [159]. Thus, it is important to understand the context of which a therapeutic approach/intervention is being utilized. With respect to skeletal muscle, where elevated PAI-1 levels have a negative impact on regeneration and function [27-29,34-37], exercise and pharmacological interventions are among the two common methods for the reduction of PAI-1. This section will shed light on the impact of exercise and pharmacological agents in lowering PAI-1 levels and their relevance in potentially improving skeletal muscle function.

\subsection{Exercise Approach}

Lifestyle choices can influence the expression of PAI-1, and as a result, can lead to negative physiological changes throughout the body. Sedentary behaviour in particular has been shown to negatively impact skeletal muscle regeneration through the aberrant activation of several pathways including inflammatory signaling and leading to fibrosis [160-162]. Furthermore, PAI-1 levels tend to be elevated even in healthy sedentary individuals [43]. A strong body of evidence has demonstrated the acute anti-fibrotic response following exercise [44-49]. Not only does exercise normalize PAI-1 levels in healthy subjects, but also in diseased populations [50-53]. Aerobic and resistance exercise have both been shown to influence tPA activity, yet acute resistance exercise may not impact PAI-1 levels to the same extent as aerobic exercise [54,55]. Nonetheless, resistance trained individuals have been found to have lower PAI-1 overall compared to their counterparts $[55,56]$, indicating a potential positive adaptation that ameliorate PAI-1 levels. An interesting point to note is the possibility of acute stress (i.e., damage) to skeletal muscle resulting in transient elevations in PAI-1 as previously shown [29] (GEO dataset: GDS234; Reference series GSE469), yet this response may only be present within skeletal muscle and may be necessary for subsequent adaptations. Nonetheless, it is still unclear whether different intensities or volume of resistance exercise elicit different effects on PAI-1. On the other hand, acute and chronic aerobic exercise elevates tPA levels as high as $180 \%$ while reducing PAI- 1 activity by almost $40 \%$ in an intensity-dependent manner [52,57]. In other words, while moderate intensity aerobic exercise was found to reduce PAI-1 levels and activity in most instances [51,57], high intensity aerobic exercise was shown to continually and significantly reduce PAI-1 levels [43,57-60]. Regardless of aerobic exercise intensity, levels of tPA remain elevated, while PAI-1 levels remain depressed by $25 \%$ for multiple hours post-exercise [51,58]. Moreover, the rigors of exercise and muscle contraction not only improve regeneration [163], but also potentiate the remodeling of the ECM through the modulation of PAI-1 within muscle.

\subsection{Pharmacological Approach}

A number of pleiotropic compounds have been identified to reduce PAI-1 levels/activity. These compounds include metformin, resveratrol, and other antioxidants. A growing body of evidence suggests that these compounds modulate different signaling cascades in distinctive ways. For instance, metformin reduces PAI- 1 content by decreasing systemic insulin levels $[164,165]$ or by inhibiting NF- $\mathrm{KB}$ by activating adenosine monophosphate-activated protein kinase (AMPK) [166]. Interestingly, metformin has also been shown to protect against muscle damage and improve regeneration [167]. 
The grape-derived phenol, resveratrol, can elevate autophagy through the activation of AMPK and inhibit TNF/NF- $\mathrm{KB} / \mathrm{ROS}$ signaling to ultimately diminish PAI-1 levels in a time- and dose-dependent manner $[168,169]$. At odds with this evidence, resveratrol has also been found to increase TGF- $\beta / S M A D$ signaling in certain cell types $[170,171]$. Antioxidants such as curcumin, ginko biloba, shikonin, theaflavin, and others can either reduce PAI-1 indirectly through the reduction of ROS [172-176] or selectively inhibit PAI-1 [61,177]. Indeed, the use of these compounds in skeletal muscle, particularly in damaged or diseased conditions, has not been investigated. Given that most of these compounds are well tolerated with minimum adverse effects and high availability, it may be worth further investigating their role in modulating the ECM through the regulation of PAI-1.

Given the clinical importance of ameliorating PAI-1 levels, numerous selective inhibitors of PAI-1 have been synthesized with some being studied in clinical trials. Most notable of these inhibitors include tiplaxtinin (PAI-039) and the three generations of TM-related drugs (TM5001, TM5009, TM5275, TM5441, TM5509, and TM5614). These inhibitors have been studied in pathological conditions including cancer, cardiovascular disease, pulmonary fibrosis renal diseases, liver diseases and others [17,22,61-68,71]. Most if not all of these inhibitors have been shown to bind the active RCL domain on PAI-1 in a reversible manner to ultimately abolish its ability to bind tPA/uPA $[16,69,70]$. PAI-039 has also been shown to bind near the somatomedin B domain on vitronectin to inhibit docking of PAI-1 to vitronectin and thereby increasing the likelihood of PAI-1 conversion to its latent conformation $[69,70]$. In the context of skeletal muscle, these inhibitors have scarcely been used. In fact, only PAI-039 has been used to investigate diabetic muscle regeneration [27], whereas the other inhibitors have not. The use of these inhibitors may provide valuable insight into the role of PAI-1, particularly pertaining to pathological conditions such as muscle dystrophy or aging. Thus, future work investigating PAI-1 should utilize these inhibitors to better understand the importance of this protein in skeletal muscle

\section{Conclusions}

In summary, this review highlights the known and prospective roles of PAI-1 in skeletal muscle with particular emphasis on injury and pathological conditions. This review also provides support for further investigation and testing of different exercise- and drug-based modalities to reduce PAI-1 levels in an attempt to improve skeletal muscle function. Indeed, numerous effects of PAI-1 on cells within muscle tissue (i.e., satellite cells, immune cells, fibrogenic cells, etc.) that have yet to be explored, and as such, future studies on PAI-1 in skeletal muscle should also investigate the implications of this protein on the various cell types found within the skeletal muscle tissue. Investigation in this manner may provide further insight into the role of PAI-1 in modulating the aberrant changes observed in skeletal muscle tissue and may provide novel insight into safety and efficacy of therapeutic approaches.

Funding: This research and the APC was funded by Natural Sciences and Engineering Research Council (NSERC) of Canada, grant number 2016-05073.

Conflicts of Interest: The authors declare no conflict of interest.

\section{Abbreviations}

$\begin{array}{ll}\text { AMPK } & \text { Adenosine monophosphate-activated protein kinase } \\ \text { AP1 } & \text { Activation protein } 1 \\ \text { ATP } & \text { Adenosine triphosphate } \\ \text { cAMP } & \text { Cyclic adenosine monophosphate } \\ \text { CREB1 } & \text { cAMP-responsible element binding protein } 1 \\ \text { ECM } & \text { Extracellular matrix } \\ \text { FDP } & \text { Fibrin degradation product }\end{array}$




$\begin{array}{ll}\text { GC } & \text { Glucocorticoid } \\ \text { GSK3 } & \text { Glycogen synthase kinase 3 } \\ \text { hD/E/F } & \text { Helix D/E/F domains } \\ \text { HIF } & \text { Hypoxia-inducing factor } \\ \text { IGF-1 } & \text { Insulin-like growth factor-1 } \\ \text { IL } & \text { Interleukin } \\ \text { LRP1 } & \text { Low density lipoprotein receptor-related protein 1 } \\ \text { MAPK } & \text { Mitogen-activated protein kinase } \\ \text { MMP } & \text { Matrix metalloproteinase } \\ \text { NF-kB } & \text { Nuclear factor kappa B } \\ \text { PAI-1 } & \text { Plasminogen activator inhibitor-1 } \\ \text { PI3K } & \text { Phosphatidylinositol 3-kinase } \\ \text { PKA } & \text { Protein kinase A } \\ \text { RCL } & \text { Reactive center loop } \\ \text { ROS } & \text { Reactive oxygen species } \\ \text { TGF- } \beta & \text { Transforming growth factor- } \beta \\ \text { TIMP } & \text { Tissue inhibitor of metalloproteinase } \\ \text { TNF } & \text { Tumor necrosis factor } \\ \text { tPA } & \text { Tissue-type plasminogen activator } \\ \text { uPA } & \text { Urokinase-type plasminogen activator } \\ \text { uPAR } & \text { Urokinase-type plasminogen activator receptor }\end{array}$

\section{References}

1. Dastre, A. Fibrinolyse dans le sang. Arch. Physiol. Norm. Pathol. 1893, 5, 661-663.

2. Macfarlane, R.G.; Pilling, J. Observations on fibrinolysis plasminogen, plasmin, and antiplasmin content of human blood. Lancet 1946, 248, 562-565. [CrossRef]

3. Christensen, L.R. The activation of plasminogen by chloroform. J. Gen. Physiol. 1946, 30, 149-157. [CrossRef] [PubMed]

4. Christensen, L.R.; Smith, D.H. Plasminogen purification by acid extraction. Proc. Soc. Exp. Biol. Med. 1950, 74, 840-844. [CrossRef] [PubMed]

5. Lewis, J.H.; Ferguson, J.H.; Howe, A.C.; Rogers, J. Studies on a proteolytic enzyme system of the blood. II. fibrinolysokinase activators for profibrinolysin. J. Clin. Investig. 1950, 29, 1059-1068. [CrossRef]

6. Kaplan, M. Inhibition of $\beta$ hemolytic streptococci fibrinolysin by trypsin inhibitor. Science 1944, 100, 198-200.

7. Kaplan, M. A quantitative study of the fibrinolysin-Antifibrinolysin reaction. Science 1945, 101, 120-122.

8. Loskutoff, D.J.; van Mourik, J.A.; Erickson, L.A.; Lawrence, D. Detection of an unusually stable fibrinolytic inhibitor produced by bovine endothelial cells. Proc. Natl. Acad. Sci. USA 1983, 80, 2956-2960. [CrossRef]

9. Ginsburg, D.; Zeheb, R.; Yang, A.Y.; Rafferty, U.M.; Andreasen, P.A.; Nielsen, L.; Dano, K.; Lebo, R.V.; Gelehrter, T.D. cDNA cloning of human plasminogen activator-inhibitor from endothelial cells. J. Clin. Investig. 1986, 78, 1673-1680. [CrossRef]

10. Balsara, R.D.; Ploplis, V.A. Plasminogen activator inhibitor-1: The double-edged sword in apoptosis. Thromb. Haemost. 2008, 100, 1029-1036. [CrossRef]

11. Lademann, U.A.; Rømer, M.U. Regulation of programmed cell death by plasminogen activator inhibitor type 1 (PAI-1). Thromb. Haemost. 2008, 100, 1041-1046. [PubMed]

12. Vaughan, D.E.; Rai, R.; Khan, S.S.; Eren, M.; Ghosh, A.K. Plasminogen activator inhibitor-1 is a marker and a mediator of senescence. Arterioscler. Thromb. Vasc. Biol. 2017, 37, 1446-1452. [CrossRef] [PubMed]

13. Samarakoon, R.; Higgins, S.P.; Higgins, C.E.; Higgins, P.J. The TGF- $\beta 1 /$ p53/PAI-1 signaling axis in vascular senescence: Role of caveolin-1. Biomolecules 2019, 9, 341. [CrossRef]

14. Aso, Y. Plasminogen activator inhibitor (PAI)-1 in vascular inflammation and thrombosis. Front. Biosci. 2007, 12, 2957-2966. [CrossRef]

15. Samad, F.; Ruf, W. Inflammation, obesity, and thrombosis. Blood 2013, 122, 3415-3422. [CrossRef] [PubMed]

16. Placencio, V.R.; DeClerck, Y.A. Plasminogen activator inhibitor-1 in cancer: Rationale and insight for future therapeutic testing. Cancer Res. 2015, 75, 2969-2974. [CrossRef] 
17. Mashiko, S.; Kitatani, K.; Toyoshima, M.; Ichimura, A.; Dan, T.; Usui, T.; Ishibashi, M.; Shigeta, S.; Nagase, S.; Miyata, T.; et al. Inhibition of plasminogen activator inhibitor-1 is a potential therapeutic strategy in ovarian cancer. Cancer Biol. Ther. 2015, 16, 253-260. [CrossRef]

18. Li, S.; Wei, X.; He, J.; Tian, X.; Yuan, S.; Sun, L. Plasminogen activator inhibitor-1 in cancer research. Biomed. Pharmacother. 2018, 105, 83-94. [CrossRef]

19. Peng, Y.; Kajiyama, H.; Yuan, H.; Nakamura, K.; Yoshihara, M.; Yokoi, A.; Fujikake, K.; Yasui, H.; Yoshikawa, N.; Suzuki, S.; et al. PAI-1 secreted from metastatic ovarian cancer cells triggers the tumor-promoting role of the mesothelium in a feedback loop to accelerate peritoneal dissemination. Cancer Lett. 2019, 442, 181-192. [CrossRef]

20. Stefansson, S.; McMahon, G.A.; Petitclerc, E.; Lawrence, D.A. Plasminogen activator inhibitor-1 in tumor growth, angiogenesis and vascular remodeling. Curr. Pharm. Des. 2003, 9, 1545-1564. [CrossRef]

21. Vaughan, D.E. PAI-1 and atherothrombosis. J. Thromb. Haemost. 2005, 3, 1879-1883. [CrossRef] [PubMed]

22. Khoukaz, H.B.; Ji, Y.; Braet, D.J.; Vadali, M.; Abdelhamid, A.A.; Emal, C.D.; Lawrence, D.A.; Fay, W.P. Drug targeting of plasminogen activator inhibitor-1 inhibits metabolic dysfunction and atherosclerosis in a murine model of metabolic syndrome. Arterioscler. Thromb. Vasc. Biol. 2020, 40, 1479-1490. [CrossRef]

23. Lyon, C.J.; Hsueh, W.A. Effect of plasminogen activator inhibitor-1 in diabetes mellitus and cardiovascular disease. Am. J. Med. 2003, 115 (Suppl. 8A), 62S-68S. [CrossRef]

24. Yarmolinsky, J.; Bordin Barbieri, N.; Weinmann, T.; Ziegelmann, P.K.; Duncan, B.B.; Inês Schmidt, M. Plasminogen activator inhibitor-1 and type 2 diabetes: A systematic review and meta-analysis of observational studies. Sci. Rep. 2016, 6, 17714. [CrossRef] [PubMed]

25. Ma, L.-J.; Fogo, A.B. PAI-1 and kidney fibrosis. Front. Biosci. 2009, 14, 2028-2041. [CrossRef] [PubMed]

26. Huang, Y.; Noble, N.A. PAI-1 as a target in kidney disease. Curr. Drug Targets 2007, 8, 1007-1015. [CrossRef] [PubMed]

27. Krause, M.P.; Moradi, J.; Nissar, A.A.; Riddell, M.C.; Hawke, T.J. Inhibition of plasminogen activator inhibitor-1 restores skeletal muscle regeneration in untreated type 1 diabetic mice. Diabetes 2011, 60, 1964-1972. [CrossRef]

28. Koh, T.J.; Bryer, S.C.; Pucci, A.M.; Sisson, T.H. Mice deficient in plasminogen activator inhibitor-1 have improved skeletal muscle regeneration. Am. J. Physiol. Cell Physiol. 2005, 289, C217-C223. [CrossRef]

29. Rahman, F.A.; Angus, S.A.; Stokes, K.; Karpowicz, P.; Krause, M.P. Impaired ECM remodeling and macrophage activity define necrosis and regeneration following damage in aged skeletal muscle. Int. J. Mol. Sci. 2020, 21, 4575. [CrossRef]

30. Naderi, J.; Bernreuther, C.; Grabinski, N.; Putman, C.T.; Henkel, B.; Bell, G.; Glatzel, M.; Sultan, K.R. Plasminogen activator inhibitor type 1 up-regulation is associated with skeletal muscle atrophy and associated fibrosis. Am. J. Pathol. 2009, 175, 763-771. [CrossRef]

31. Flevaris, P.; Vaughan, D. The role of plasminogen activator inhibitor type-1 in fibrosis. Semin. Thromb. Hemost. 2017, 43, 169-177. [CrossRef]

32. Ghosh, A.K.; Vaughan, D.E. PAI-1 in tissue fibrosis. J. Cell. Physiol. 2012, 227, 493-507. [CrossRef] [PubMed]

33. Cesari, M.; Pahor, M.; Incalzi, R.A. Plasminogen activator inhibitor-1 (pai-1): A key factor linking fibrinolysis and age-related subclinical and clinical conditions. Cardiovasc. Ther. 2010, 28, e72-e91. [CrossRef]

34. Ardite, E.; Perdiguero, E.; Vidal, B.; Gutarra, S.; Serrano, A.L.; Muñoz-Cánoves, P. PAI-1-regulated miR-21 defines a novel age-associated fibrogenic pathway in muscular dystrophy. J. Cell Biol. 2012, 196, 163-175. [CrossRef]

35. Suelves, M.; Vidal, B.; Serrano, A.L.; Tjwa, M.; Roma, J.; López-Alemany, R.; Luttun, A.; de Lagrán, M.M.; Díaz-Ramos, A.; Díaz, M.A.; et al. uPA deficiency exacerbates muscular dystrophy in MDX mice. J. Cell Biol. 2007, 178, 1039-1051. [CrossRef] [PubMed]

36. Suelves, M.; Vidal, B.; Ruiz, V.; Baeza-Raja, B.; Diaz-Ramos, A.; Cuartas, I.; Lluis, F.; Parra, M.; Jardi, M.; Lopez-Alemany, R.; et al. The plasminogen activation system in skeletal muscle regeneration: Antagonistic roles of urokinase-type plasminogen activator (uPA) and its inhibitor (PAI-1). Front. Biosci. 2005, 10, 2978-2985. [CrossRef] [PubMed]

37. Suelves, M.; López-Alemany, R.; Lluís, F.; Aniorte, G.; Serrano, E.; Parra, M.; Carmeliet, P.; Muñoz-Cánoves, P. Plasmin activity is required for myogenesis in vitro and skeletal muscle regeneration in vivo. Blood 2002, 99, 2835-2844. [CrossRef] [PubMed] 
38. Lluís, F.; Roma, J.; Suelves, M.; Parra, M.; Aniorte, G.; Gallardo, E.; Illa, I.; Rodríguez, L.; Hughes, S.M.; Carmeliet, P.; et al. Urokinase-dependent plasminogen activation is required for efficient skeletal muscle regeneration in vivo. Blood 2001, 97, 1703-1711. [CrossRef]

39. Fibbi, G.; Barletta, E.; Dini, G.; Del Rosso, A.; Pucci, M.; Cerletti, M.; Del Rosso, M. Cell invasion is affected by differential expression of the urokinase plasminogen activator/urokinase plasminogen activator receptor system in muscle satellite cells from normal and dystrophic patients. Lab. Investig. 2001, 81, 27-39. [CrossRef]

40. Muñoz-Cánoves, P.; Miralles, F.; Baiget, M.; Félez, J. Inhibition of urokinase-type plasminogen activator (uPA) abrogates myogenesis in vitro. Thromb. Haemost. 1997, 77, 526-534. [CrossRef]

41. Dadgar, S.; Wang, Z.; Johnston, H.; Kesari, A.; Nagaraju, K.; Chen, Y.-W.; Hill, D.A.; Partridge, T.A.; Giri, M.; Freishtat, R.J.; et al. Asynchronous remodeling is a driver of failed regeneration in Duchenne muscular dystrophy. J. Cell Biol. 2014, 207, 139-158. [CrossRef]

42. Zhao, P.; Iezzi, S.; Carver, E.; Dressman, D.; Gridley, T.; Sartorelli, V.; Hoffman, E.P. Slug is a novel downstream target of MyoD. Temporal profiling in muscle regeneration. J. Biol. Chem. 2002, 277, 30091-30101. [CrossRef]

43. Lira, F.S.; Rosa, J.C.; Lima-Silva, A.E.; Souza, H.A.; Caperuto, E.C.; Seelaender, M.C.; Damaso, A.R.; Oyama, L.M.; Santos, R.V. Sedentary subjects have higher PAI-1 and lipoproteins levels than highly trained athletes. Diabetol. Metab. Syndr. 2010, 2, 7. [CrossRef]

44. Davis, G.L.; Abildgaard, C.F.; Bernauer, E.M.; Britton, M. Fibrinolytic and hemostatic changes during and after maximal exercise in males. J. Appl. Physiol. 1976, 40, 287-292. [CrossRef]

45. Fernhall, B.; Szymanski, L.M.; Gorman, P.A.; Milani, J.; Paup, D.C.; Kessler, C.M. Fibrinolytic activity is not dependent upon exercise mode in post-myocardial infarction patients. Eur. J. Appl. Physiol. 1998, 78, $247-252$. [CrossRef]

46. Hilberg, T.; Nowacki, P.E.; Müller-Berghaus, G.; Gabriel, H.H. Changes in blood coagulation and fibrinolysis associated with maximal exercise and physical conditioning in women taking low dose oral contraceptives. J. Sci. Med. Sport 2000, 3, 383-390. [CrossRef]

47. Röcker, L.; Taenzer, M.; Drygas, W.K.; Lill, H.; Heyduck, B.; Altenkirch, H.U. Effect of prolonged physical exercise on the fibrinolytic system. Eur. J. Appl. Physiol. Occup. Physiol. 1990, 60, 478-481. [CrossRef]

48. Wheeler, M.E.; Davis, G.L.; Gillespie, W.J.; Bern, M.M. Physiological changes in hemostasis associated with acute exercise. J. Appl. Physiol. 1986, 60, 986-990. [CrossRef]

49. Winther, K.; Hillegass, W.; Tofler, G.H.; Jimenez, A.; Brezinski, D.A.; Schafer, A.I.; Loscalzo, J.; Williams, G.H.; Muller, J.E. Effects on platelet aggregation and fibrinolytic activity during upright posture and exercise in healthy men. Am. J. Cardiol. 1992, 70, 1051-1055. [CrossRef]

50. Sakata, K.; Kurata, C.; Taguchi, T.; Suzuki, S.; Kobayashi, A.; Yamazaki, N.; Rydzewski, A.; Takada, Y.; Takada, A. Clinical significance of plasminogen activator inhibitor activity in patients with exercise-induced ischemia. Am. Heart J. 1990, 120, 831-838. [CrossRef]

51. Ivey, F.M.; Womack, C.J.; Kulaputana, O.; Dobrovolny, C.L.; Wiley, L.A.; Macko, R.F. A single bout of walking exercise enhances endogenous fibrinolysis in stroke patients. Med. Sci. Sports Exerc. 2003, 35, 193-198. [CrossRef]

52. Womack, C.J.; Ivey, F.M.; Gardner, A.W.; Macko, R.F. Fibrinolytic response to acute exercise in patients with peripheral arterial disease. Med. Sci. Sports Exerc. 2001, 33, 214-219. [CrossRef]

53. Svendsen, O.L.; Hassager, C.; Christiansen, C.; Nielsen, J.D.; Winther, K. Plasminogen activator inhibitor-1, tissue-type plasminogen activator, and fibrinogen. Arterioscler. Thromb. Vasc. Biol. 1996, 16, 381-385. [CrossRef]

54. Nagelkirk, P.R.; Scalzo, R.; Harber, M.; Kaminsky, L.A. The influence of acute resistance training and body composition on coagulation and fibrinolytic activity in low-risk women. Int. J. Sports Med. 2010, 31, 458-462. [CrossRef]

55. Kupchak, B.R.; Creighton, B.C.; Aristizabal, J.C.; Dunn-Lewis, C.; Volk, B.M.; Ballard, K.D.; Comstock, B.A.; Maresh, C.M.; Kraemer, W.J.; Volek, J.S. Beneficial effects of habitual resistance exercise training on coagulation and fibrinolytic responses. Thromb. Res. 2013, 131, e227-e234. [CrossRef]

56. Rossi, F.E.; Gerosa-Neto, J.; Diniz, T.A.; Freitas, I.F.; Lira, F.S.; Cholewa, J.M. Moderate rest intervals are superior to short intervals for improving PAI-1 following exhaustive exercise in recreational weightlifters. J. Exerc. Rehabil. 2016, 12, 559-566. [CrossRef]

57. Szymanski, L.M.; Pate, R.R. Effects of exercise intensity, duration, and time of day on fibrinolytic activity in physically active men. Med. Sci. Sports Exerc. 1994, 26, 1102-1108. [CrossRef] 
58. Cooper, J.A.; Nagelkirk, P.R.; Coughlin, A.M.; Pivarnik, J.M.; Womack, C.J. Temporal changes in tPA and PAI-1 after maximal exercise. Med. Sci. Sports Exerc. 2004, 36, 1884-1887. [CrossRef]

59. Booth, N.A.; Walker, E.; Maughan, R.; Bennett, B. Plasminogen activator in normal subjects after exercise and venous occlusion: T-PA circulates as complexes with C1-inhibitor and PAI-1. Blood 1987, 69, 1600-1604. [CrossRef]

60. Schuit, A.J.; Schouten, E.G.; Kluft, C.; de Maat, M.; Menheere, P.P.; Kok, F.J. Effect of strenuous exercise on fibrinogen and fibrinolysis in healthy elderly men and women. Thromb. Haemost. 1997, 78, 845-851. [CrossRef]

61. Van Giezen, J.J.J.; Wahlund, G.; Nerme, V.; Abrahamsson, T. The fab-fragment of a PAI-1 inhibiting antibody reduces thrombus size and restores blood flow in a rat model of arterial thrombosis. Thromb. Haemost. 1997, 77, 964-969. [CrossRef]

62. Akhter, H.; Huang, W.-T.; van Groen, T.; Kuo, H.-C.; Miyata, T.; Liu, R.-M. A small molecule inhibitor of plasminogen activator inhibitor-1 reduces brain amyloid- $\beta$ load and improves memory in an animal model of alzheimer's disease. J. Alzheimer's Dis. 2018, 64, 447-457. [CrossRef]

63. Hennan, J.K.; Elokdah, H.; Leal, M.; Ji, A.; Friedrichs, G.S.; Morgan, G.A.; Swillo, R.E.; Antrilli, T.M.; Hreha, A.; Crandall, D.L. Evaluation of PAI-039 [\{1-benzyl-5-[4-(trifluoromethoxy)phenyl]-1H-indol-3-yl\}(oxo)acetic acid], a novel plasminogen activator inhibitor-1 inhibitor, in a canine model of coronary artery thrombosis. J. Pharmacol. Exp. Ther. 2005, 314, 710-716. [CrossRef]

64. Huang, W.-T.; Akhter, H.; Jiang, C.; MacEwen, M.; Ding, Q.; Antony, V.; Thannickal, V.J.; Liu, R.-M. Plasminogen activator inhibitor 1, fibroblast apoptosis resistance, and aging-related susceptibility to lung fibrosis. Exp. Gerontol. 2015, 61, 62-75. [CrossRef]

65. Izuhara, Y.; Yamaoka, N.; Kodama, H.; Dan, T.; Takizawa, S.; Hirayama, N.; Meguro, K.; Strihou, C.V.Y.D.; Miyata, T. A novel inhibitor of plasminogen activator inhibitor-1 provides antithrombotic benefits devoid of bleeding effect in nonhuman primates. J. Cereb. Blood Flow Metab. 2010, 30, 904-912. [CrossRef]

66. Liu, R.-M.; Eldridge, S.; Watanabe, N.; Deshane, J.; Kuo, H.-C.; Jiang, C.; Wang, Y.; Liu, G.; Schwiebert, L.; Miyata, T.; et al. Therapeutic potential of an orally effective small molecule inhibitor of plasminogen activator inhibitor for asthma. Am. J. Physiol. Lung Cell Mol. Physiol. 2016, 310, L328-L336. [CrossRef]

67. Liu, Y.; Wang, L.; Luo, M.; Chen, N.; Deng, X.; He, J.; Zhang, L.; Luo, P.; Wu, J. Inhibition of PAI-1 attenuates perirenal fat inflammation and the associated nephropathy in high-fat diet-induced obese mice. Am. J. Physiol. Endocrinol. Metab. 2019, 316, E260-E267. [CrossRef]

68. Tashiro, Y.; Nishida, C.; Sato-Kusubata, K.; Ohki-Koizumi, M.; Ishihara, M.; Sato, A.; Gritli, I.; Komiyama, H.; Sato, Y.; Dan, T.; et al. Inhibition of PAI-1 induces neutrophil-driven neoangiogenesis and promotes tissue regeneration via production of angiocrine factors in mice. Blood 2012, 119, 6382-6393. [CrossRef]

69. Leik, C.E.; Su, E.J.; Nambi, P.; Crandall, D.L.; Lawrence, D.A. Effect of pharmacologic plasminogen activator inhibitor-1 inhibition on cell motility and tumor angiogenesis. J. Thromb. Haemost. 2006, 4, 2710-2715. [CrossRef]

70. Gorlatova, N.V.; Cale, J.M.; Elokdah, H.; Li, D.; Fan, K.; Warnock, M.; Crandall, D.L.; Lawrence, D.A. Mechanism of inactivation of plasminogen activator inhibitor-1 by a small molecule inhibitor. J. Biol. Chem. 2007, 282, 9288-9296. [CrossRef]

71. Cale, J.M.; Lawrence, D.A. Structure-function relationships of plasminogen activator inhibitor-1 and its potential as a therapeutic agent. Curr. Drug Targets 2007, 8, 971-981. [CrossRef]

72. Boudier, C.; Gils, A.; Declerck, P.J.; Bieth, J.G. The Conversion of Active to Latent Plasminogen Activator Inhibitor-1 Is an Energetically Silent Event. Biophys. J. 2005, 88, 2848-2854. [CrossRef] [PubMed]

73. Lawrence, D.A.; Ginsburg, D.; Day, D.E.; Berkenpas, M.B.; Verhamme, I.M.; Kvassman, J.O.; Shore, J.D. Serpin-protease complexes are trapped as stable acyl-enzyme intermediates. J. Biol. Chem. 1995, 270, 25309-25312. [CrossRef]

74. Wilczynska, M.; Fa, M.; Ohlsson, P.I.; Ny, T. The inhibition mechanism of serpins. Evidence that the mobile reactive center loop is cleaved in the native protease-inhibitor complex. J. Biol. Chem. 1995, 270, 29652-29655. [CrossRef] [PubMed]

75. Dupont, D.M.; Madsen, J.B.; Kristensen, T.; Bodker, J.S.; Blouse, G.E.; Wind, T.; Andreasen, P.A. Biochemical properties of plasminogen activator inhibitor-1. Front. Biosci. 2009, 14, 1337-1361. [CrossRef] 
76. Schroeck, F.R.; De Prada, N.A.; Sperl, S.; Schmitt, M.; Magdolen, V. Interaction of plasminogen activator inhibitor type-1 (PAI-1) with vitronectin (Vn): Mapping the binding sites on PAI-1 and Vn. Biol. Chem. 2002, 383, 1143-1149. [CrossRef]

77. Wind, T.; Hansen, M.; Jensen, J.K.; Andreasen, P.A. The molecular basis for anti-proteolytic and non-proteolytic functions of plasminogen activator inhibitor type-1: Roles of the reactive centre loop, the shutter region, the flexible joint region and the small serpin fragment. Biol. Chem. 2002, 383, 21-36. [CrossRef]

78. Gibson, A.; Baburaj, K.; Day, D.E.; Verhamme, I.; Shore, J.D.; Peterson, C.B. The use of fluorescent probes to characterize conformational changes in the interaction between vitronectin and plasminogen activator inhibitor-1. J. Biol. Chem. 1997, 272, 5112-5121. [CrossRef]

79. Kjøller, L. The urokinase plasminogen activator receptor in the regulation of the actin cytoskeleton and cell motility. Biol. Chem. 2002, 383, 5-19. [CrossRef]

80. Mondino, A.; Resnati, M.; Blasi, F. Structure and Function of the Urokinase Receptor. Thromb. Haemost. 1999, 82, 19-22. [CrossRef]

81. Wei, Y.; Eble, J.A.; Wang, Z.; Kreidberg, J.A.; Chapman, H.A. Urokinase receptors promote beta1 integrin function through interactions with integrin alpha3beta1. Mol. Biol. Cell 2001, 12, 2975-2986. [CrossRef]

82. Chapman, H.A.; Wei, Y. Protease crosstalk with integrins: The urokinase receptor paradigm. Thromb. Haemost. 2001, 86, 124-129.

83. Stefansson, S.; Lawrence, D.A. The serpin PAI-1 inhibits cell migration by blocking integrin alpha V beta 3 binding to vitronectin. Nature 1996, 383, 441-443. [CrossRef]

84. Stefansson, S.; Lawrence, D.A. Old dogs and new tricks: Proteases, inhibitors, and cell migration. Sci. STKE 2003, 2003, pe24. [CrossRef]

85. Deng, G.; Royle, G.; Wang, S.; Crain, K.; Loskutoff, D.J. Structural and functional analysis of the plasminogen activator inhibitor-1 binding motif in the somatomedin B domain of vitronectin. J. Biol. Chem. 1996, 271, 12716-12723. [CrossRef]

86. Cubellis, M.V.; Wun, T.C.; Blasi, F. Receptor-mediated internalization and degradation of urokinase is caused by its specific inhibitor PAI-1. EMBO J. 1990, 9, 1079-1085. [CrossRef]

87. Al-Fakhri, N.; Chavakis, T.; Schmidt-Wöll, T.; Huang, B.; Cherian, S.M.; Bobryshev, Y.V.; Lord, R.S.A.; Katz, N.; Preissner, K.T. Induction of apoptosis in vascular cells by plasminogen activator inhibitor-1 and high molecular weight kininogen correlates with their anti-adhesive properties. Biol. Chem. 2003, 384, 423-435. [CrossRef] [PubMed]

88. Lawrence, D.A.; Olson, S.T.; Palaniappan, S.; Ginsburg, D. Engineering plasminogen activator inhibitor-1 mutants with increased functional stability. Biochemistry 1994, 33, 3643-3648. [CrossRef] [PubMed]

89. Berkenpas, M.B.; Lawrence, D.A.; Ginsburg, D. Molecular evolution of plasminogen activator inhibitor-1 functional stability. EMBO J. 1995, 14, 2969-2977. [CrossRef] [PubMed]

90. Fjellström, O.; Deinum, J.; Sjögren, T.; Johansson, C.; Geschwindner, S.; Nerme, V.; Legnehed, A.; McPheat, J.; Olsson, K.; Bodin, C.; et al. Characterization of a small molecule inhibitor of plasminogen activator inhibitor type 1 that accelerates the transition into the latent conformation. J. Biol. Chem. 2013, 288, 873-885. [CrossRef]

91. Ehnebom, J.; Pusa, S.; Björquist, P.; Deinum, J. Comparison of chromogenic substrates for tissue plasminogen activator and the effects on the stability of plasminogen activator inhibitor type-1. Fibrinolysis Proteolysis 1997, 11, 287-293. [CrossRef]

92. Hekman, C.M.; Loskutoff, D.J. Endothelial cells produce a latent inhibitor of plasminogen activators that can be activated by denaturants. J. Biol. Chem. 1985, 260, 11581-11587.

93. Vaughan, D.E.; Declerck, P.J.; Van Houtte, E.; De Mol, M.; Collen, D. Studies of recombinant plasminogen activator inhibitor-1 in rabbits. Pharmacokinetics and evidence for reactivation of latent plasminogen activator inhibitor-1 in vivo. Circ. Res. 1990, 67, 1281-1286. [CrossRef] [PubMed]

94. Reilly, C.F.; Hutzelmann, J.E. Plasminogen activator inhibitor-1 binds to fibrin and inhibits tissue-type plasminogen activator-mediated fibrin dissolution. J. Biol. Chem. 1992, 267, 17128-17135.

95. Lee, E.; Vaughan, U.E.; Parikh, S.H.; Grodzinsky, A.J.; Libby, P.; Lark, M.W.; Lee, R.T. Regulation of Matrix Metalloproteinases and Plasminogen Activator Inhibitor-1 Synthesis by Plasminogen in Cultured Human Vascular Smooth Muscle Cells. Circ. Res. 1996, 78, 44-49. [CrossRef]

96. Duymelinck, C.; Dauwe, S.E.; De Greef, K.E.; Ysebaert, D.K.; Verpooten, G.A.; De Broe, M.E. TIMP-1 gene expression and PAI-1 antigen after unilateral ureteral obstruction in the adult male rat. Kidney Int. 2000, 58, 1186-1201. [CrossRef] 
97. Ahmed, M.M.; King, K.C.; Pearce, S.M.; Ramsey, M.A.; Miranpuri, G.S.; Resnick, D.K. Novel target for Spinal Cord Injury related neuropathic pain. Ann. Neurosci. 2011, 18, 162-167. [CrossRef]

98. Leivonen, S.-K.; Lazaridis, K.; Decock, J.; Chantry, A.; Edwards, D.R.; Kähäri, V.-M. TGF- $\beta$-Elicited Induction of Tissue Inhibitor of Metalloproteinases (TIMP)-3 Expression in Fibroblasts Involves Complex Interplay between Smad3, p38 $\alpha$, and ERK1/2. PLoS ONE 2013, 8, e57474. [CrossRef]

99. Clark, I.M.; Rowan, A.D.; Edwards, D.R.; Bech-Hansen, T.; Mann, D.A.; Bahr, M.J.; Cawston, T.E. Transcriptional activity of the human tissue inhibitor of metalloproteinases 1 (TIMP-1) gene in fibroblasts involves elements in the promoter, exon 1 and intron 1. Biochem. J. 1997, 324 Pt 2, 611-617. [CrossRef]

100. Qureshi, H.Y.; Sylvester, J.; El Mabrouk, M.; Zafarullah, M. TGF-beta-induced expression of tissue inhibitor of metalloproteinases- 3 gene in chondrocytes is mediated by extracellular signal-regulated kinase pathway and Sp1 transcription factor. J. Cell. Physiol. 2005, 203, 345-352. [CrossRef]

101. Stout, T.J.; Graham, H.; Buckley, D.I.; Matthews, D.J. Structures of active and latent PAI-1: A possible stabilizing role for chloride ions. Biochemistry 2000, 39, 8460-8469. [CrossRef] [PubMed]

102. Jensen, J.K.; Gettins, P.G.W. High-resolution structure of the stable plasminogen activator inhibitor type-1 variant 14-1B in its proteinase-cleaved form: A new tool for detailed interaction studies and modeling. Protein Sci. 2008, 17, 1844-1849. [CrossRef] [PubMed]

103. Oishi, K. Plasminogen activator inhibitor-1 and the circadian clock in metabolic disorders. Clin. Exp. Hypertens. 2009, 31, 208-219. [CrossRef] [PubMed]

104. Lund, L.R.; Riccio, A.; Andreasen, P.A.; Nielsen, L.S.; Kristensen, P.; Laiho, M.; Saksela, O.; Blasi, F.; Danø, K. Transforming growth factor-beta is a strong and fast acting positive regulator of the level of type-1 plasminogen activator inhibitor mRNA in WI-38 human lung fibroblasts. EMBO J. 1987, 6, 1281-1286. [CrossRef] [PubMed]

105. Keski-Oja, J.; Raghow, R.; Sawdey, M.; Loskutoff, D.J.; Postlethwaite, A.E.; Kang, A.H.; Moses, H.L. Regulation of mRNAs for type-1 plasminogen activator inhibitor, fibronectin, and type I procollagen by transforming growth factor-beta. Divergent responses in lung fibroblasts and carcinoma cells. J. Biol. Chem. 1988, 263, 3111-3115.

106. Kwon, I.-S.; Kim, J.; Rhee, D.-K.; Kim, B.-O.; Pyo, S. Pneumolysin induces cellular senescence by increasing ROS production and activation of MAPK/NF-KB signal pathway in glial cells. Toxicon 2017, 129, 100-112. [CrossRef]

107. You, W.; Hong, Y.; He, H.; Huang, X.; Tao, W.; Liang, X.; Zhang, Y.; Li, X. TGF- $\beta$ mediates aortic smooth muscle cell senescence in Marfan syndrome. Aging 2019, 11, 3574-3584. [CrossRef]

108. Jain, M.; Rivera, S.; Monclus, E.A.; Synenki, L.; Zirk, A.; Eisenbart, J.; Feghali-Bostwick, C.; Mutlu, G.M.; Budinger, G.R.S.; Chandel, N.S. mitochondrial reactive oxygen species regulate transforming growth factor- $\beta$ signaling. J. Biol. Chem. 2013, 288, 770-777. [CrossRef]

109. Jaffer, O.A.; Carter, A.B.; Sanders, P.N.; Dibbern, M.E.; Winters, C.J.; Murthy, S.; Ryan, A.J.; Rokita, A.G.; Prasad, A.M.; Zabner, J.; et al. Mitochondrial-targeted antioxidant therapy decreases transforming growth factor- $\beta$-mediated collagen production in a murine asthma model. Am. J. Respir. Cell Mol. Biol. 2015, 52, 106-115. [CrossRef]

110. Jiang, Z.; Seo, J.Y.; Ha, H.; Lee, E.A.; Kim, Y.S.; Han, D.C.; Uh, S.T.; Park, C.S.; Lee, H.B. Reactive oxygen species mediate TGF-beta1-induced plasminogen activator inhibitor-1 upregulation in mesangial cells. Biochem. Biophys. Res. Commun. 2003, 309, 961-966. [CrossRef]

111. Samarakoon, R.; Chitnis, S.S.; Higgins, S.P.; Higgins, C.E.; Krepinsky, J.C.; Higgins, P.J. Redox-Induced Src Kinase and Caveolin-1 Signaling in TGF- $\beta 1$-Initiated SMAD2/3 Activation and PAI-1 Expression. PLoS ONE 2011, 6, e22896. [CrossRef]

112. Higgins, S.P.; Tang, Y.; Higgins, C.E.; Mian, B.; Zhang, W.; Czekay, R.-P.; Samarakoon, R.; Conti, D.J.; Higgins, P.J. TGF- $\beta 1 /$ p53 signaling in renal fibrogenesis. Cell. Signal. 2018, 43, 1-10. [CrossRef] [PubMed]

113. Liao, H.; Hyman, M.C.; Lawrence, D.A.; Pinsky, D.J. Molecular regulation of the PAI-1 gene by hypoxia: Contributions of Egr-1, HIF-1 $\alpha$, and C/EBP $\alpha$. FASEB J. 2007, 21, 935-949. [CrossRef] [PubMed]

114. Bonello, S.; Zähringer, C.; BelAiba, R.S.; Djordjevic, T.; Hess, J.; Michiels, C.; Kietzmann, T.; Görlach, A. Reactive oxygen species activate the HIF-1alpha promoter via a functional NFkappaB site. Arterioscler. Thromb. Vasc. Biol. 2007, 27, 755-761. [CrossRef] 
115. Fink, T.; Kazlauskas, A.; Poellinger, L.; Ebbesen, P.; Zachar, V. Identification of a tightly regulated hypoxia-response element in the promoter of human plasminogen activator inhibitor-1. Blood 2002, 99, 2077-2083. [CrossRef]

116. Westerhausen, D.R.; Hopkins, W.E.; Billadello, J.J. Multiple transforming growth factor-beta-inducible elements regulate expression of the plasminogen activator inhibitor type-1 gene in Hep G2 cells. J. Biol. Chem. 1991, 266, 1092-1100.

117. Dimova, E.Y.; Kietzmann, T. Metabolic, hormonal and environmental regulation of plasminogen activator inhibitor-1 (PAI-1) expression: Lessons from the liver. Thromb. Haemost. 2008, 100, 992-1006. [CrossRef]

118. Sakamoto, T.; Woodcock-Mitchell, J.; Marutsuka, K.; Mitchell, J.J.; Sobel, B.E.; Fujii, S. TNF-alpha and insulin, alone and synergistically, induce plasminogen activator inhibitor-1 expression in adipocytes. Am. J. Physiol. 1999, 276, C1391-C1397. [CrossRef]

119. Hou, B.; Eren, M.; Painter, C.A.; Covington, J.W.; Dixon, J.D.; Schoenhard, J.A.; Vaughan, D.E. Tumor necrosis factor alpha activates the human plasminogen activator inhibitor-1 gene through a distal nuclear factor kappaB site. J. Biol. Chem. 2004, 279, 18127-18136. [CrossRef]

120. Chen, Y.; Zheng, Y.; Liu, L.; Lin, C.; Liao, C.; Xin, L.; Zhong, S.; Cheng, Q.; Zhang, L. Adiponectin Inhibits TNF- $\alpha$-Activated PAI-1 Expression Via the cAMP-PKA-AMPK-NF- $\kappa$ B Axis in Human Umbilical Vein Endothelial Cells. Cell. Physiol. Biochem. 2017, 42, 2342-2352. [CrossRef]

121. Kocić, J.; Santibañez, J.F.; Krstić, A.; Mojsilović, S.; Ilić, V.; Bugarski, D. Interleukin-17 modulates myoblast cell migration by inhibiting urokinase type plasminogen activator expression through p38 mitogen-activated protein kinase. Int. J. Biochem. Cell Biol. 2013, 45, 464-475. [CrossRef] [PubMed]

122. Dawson, S.J.; Wiman, B.; Hamsten, A.; Green, F.; Humphries, S.; Henney, A.M. The two allele sequences of a common polymorphism in the promoter of the plasminogen activator inhibitor-1 (PAI-1) gene respond differently to interleukin-1 in HepG2 cells. J. Biol. Chem. 1993, 268, 10739-10745. [PubMed]

123. Nordt, T.K.; Bode, C.; Sobel, B.E. Stimulation in vivo of expression of intra-abdominal adipose tissue plasminogen activator inhibitor Type I by proinsulin. Diabetologia 2001, 44, 1121-1124. [CrossRef] [PubMed]

124. Heaton, J.H.; Nebes, V.L.; O’Dell, L.G.; Morris, S.M.; Gelehrter, T.D. Glucocorticoid and cyclic nucleotide regulation of plasminogen activator and plasminogen activator-inhibitor gene expression in primary cultures of rat hepatocytes. Mol. Endocrinol. 1989, 3, 185-192. [CrossRef]

125. Tidball, J.G. Inflammatory processes in muscle injury and repair. Am. J. Physiol. Regul. Integr. Comp. Physiol. 2005, 288, R345-R353. [CrossRef]

126. Bryer, S.C.; Koh, T.J. The urokinase-type plasminogen activator receptor is not required for skeletal muscle inflammation or regeneration. Am. J. Physiol. Regul. Integr. Comp. Physiol. 2007, 293, R1152-R1158. [CrossRef]

127. Novak, M.L.; Bryer, S.C.; Cheng, M.; Nguyen, M.-H.; Conley, K.L.; Cunningham, A.K.; Xue, B.; Sisson, T.H.; You, J.-S.; Hornberger, T.A.; et al. Macrophage-specific expression of urokinase-type plasminogen activator promotes skeletal muscle regeneration. J. Immunol. 2011, 187, 1448-1457. [CrossRef]

128. Krause, M.P.; Al-Sajee, D.; D’Souza, D.M.; Rebalka, I.A.; Moradi, J.; Riddell, M.C.; Hawke, T.J. Impaired Macrophage and Satellite Cell Infiltration Occurs in a Muscle-Specific Fashion Following Injury in Diabetic Skeletal Muscle. PLoS ONE 2013, 8. [CrossRef]

129. Hawke, T.J.; Garry, D.J. Myogenic satellite cells: Physiology to molecular biology. J. Appl. Physiol. 2001, 91, 534-551. [CrossRef]

130. Dumont, N.A.; Wang, Y.X.; Rudnicki, M.A. Intrinsic and extrinsic mechanisms regulating satellite cell function. Development 2015, 142, 1572-1581. [CrossRef]

131. Kherif, S.; Dehaupas, M.; Lafuma, C.; Fardeau, M.; Alameddine, H.S. Matrix metalloproteinases MMP-2 and MMP-9 in denervated muscle and injured nerve. Neuropathol. Appl. Neurobiol. 1998, 24, 309-319. [CrossRef]

132. Tamura, Y.; Kawao, N.; Shimoide, T.; Okada, K.; Matsuo, O.; Kaji, H. Role of plasminogen activator inhibitor-1 in glucocorticoid-induced muscle change in mice. J. Bone Miner. Metab. 2018, 36, 148-156. [CrossRef]

133. Elfahime, E.; Mills, P.; Lafreniere, J.F.; Torrente, Y.; Tremblay, J.P. The urokinase plasminogen activator: An interesting way to improve myoblast migration following their transplantation. Exp. Cell Res. 2002, 280, 169-178. [CrossRef] [PubMed]

134. Kherif, S.; Lafuma, C.; Dehaupas, M.; Lachkar, S.; Fournier, J.G.; Verdière-Sahuqué, M.; Fardeau, M.; Alameddine, H.S. Expression of matrix metalloproteinases 2 and 9 in regenerating skeletal muscle: A study in experimentally injured and mdx muscles. Dev. Biol. 1999, 205, 158-170. [CrossRef] 
135. Lei, H.; Leong, D.; Smith, L.R.; Barton, E.R. Matrix metalloproteinase 13 is a new contributor to skeletal muscle regeneration and critical for myoblast migration. Am. J. Physiol. Cell Physiol. 2013, 305, C529-C538. [CrossRef]

136. Lewis, M.P.; Tippett, H.L.; Sinanan, A.C.M.; Morgan, M.J.; Hunt, N.P. Gelatinase-B (Matrix Metalloproteinase-9; MMP-9) secretion is involved in the migratory phase of human and murine muscle cell cultures. J. Muscle Res. Cell Motil. 2000, 21, 223-233. [CrossRef] [PubMed]

137. Zimowska, M.; Brzoska, E.; Swierczynska, M.; Streminska, W.; Moraczewski, J. Distinct patterns of MMP-9 and MMP-2 activity in slow and fast twitch skeletal muscle regeneration in vivo. Int. J. Dev. Biol. 2008, 52, 307-314. [CrossRef] [PubMed]

138. Elfahime, E.; Torrente, Y.; Caron, N.J.; Bresolin, M.D.; Tremblay, J.P. In Vivo Migration of Transplanted Myoblasts Requires Matrix Metalloproteinase Activity. Exp. Cell Res. 2000, 258, 279-287. [CrossRef] [PubMed]

139. Lluri, G.; Jaworski, D.M. Regulation of TIMP-2, MT1-MMP, and MMP-2 expression during C2C12 differentiation. Muscle Nerve 2005, 32, 492-499. [CrossRef]

140. Bedair, H.; Liu, T.T.; Kaar, J.L.; Badlani, S.; Russell, A.J.; Li, Y.; Huard, J. Matrix metalloproteinase-1 therapy improves muscle healing. J. Appl. Physiol. 2007, 102, 2338-2345. [CrossRef] [PubMed]

141. Kaar, J.L.; Li, Y.; Blair, H.C.; Asche, G.; Koepsel, R.R.; Huard, J.; Russell, A.J. Matrix metalloproteinase-1 treatment of muscle fibrosis. Acta Biomater. 2008, 4, 1411-1420. [CrossRef] [PubMed]

142. Wang, W.; Pan, H.; Murray, K.; Jefferson, B.S.; Li, Y. Matrix metalloproteinase-1 promotes muscle cell migration and differentiation. Am. J. Pathol. 2009, 174, 541-549. [CrossRef] [PubMed]

143. Smith, L.R.; Kok, H.J.; Zhang, B.; Chung, D.; Spradlin, R.A.; Rakoczy, K.D.; Lei, H.; Boesze-Battaglia, K.; Barton, E.R. Matrix Metalloproteinase 13 from Satellite Cells is Required for Efficient Muscle Growth and Regeneration. Cell. Physiol. Biochem. 2020, 54, 333-353. [CrossRef]

144. Zellweger, H.; Antonik, A. Newborn screening for Duchenne muscular dystrophy. Pediatrics 1975, 55, 30-34. [CrossRef]

145. Fibbi, G.; D'Alessio, S.; Pucci, M.; Cerletti, M.; Del Rosso, M. Growth factor-dependent proliferation and invasion of muscle satellite cells require the cell-associated fibrinolytic system. Biol. Chem. 2002, 383, 127-136. [CrossRef] [PubMed]

146. Krause, M.P.; Riddell, M.C.; Hawke, T.J. Effects of type 1 diabetes mellitus on skeletal muscle: Clinical observations and physiological mechanisms. Pediatr. Diabetes 2011, 12, 345-364. [CrossRef]

147. Krause, M.P.; Riddell, M.C.; Gordon, C.S.; Imam, S.A.; Cafarelli, E.; Hawke, T.J. Diabetic myopathy differs between Ins2Akita+/- and streptozotocin-induced Type 1 diabetic models. J. Appl. Physiol. 2009, 106, 1650-1659. [CrossRef]

148. Monaco, C.M.F.; Hughes, M.C.; Ramos, S.V.; Varah, N.E.; Lamberz, C.; Rahman, F.A.; McGlory, C.; Tarnopolsky, M.A.; Krause, M.P.; Laham, R.; et al. Altered mitochondrial bioenergetics and ultrastructure in the skeletal muscle of young adults with type 1 diabetes. Diabetologia 2018, 61, 1411-1423. [CrossRef]

149. D'Souza, D.M.; Al-Sajee, D.; Hawke, T.J. Diabetic myopathy: Impact of diabetes mellitus on skeletal muscle progenitor cells. Front. Physiol. 2013, 4, 4. [CrossRef]

150. Zeitler, P.; Thiede, A.; Müller, H.L. Prospective study on plasma clotting parameters in diabetic children-No evidence for specific changes in coagulation system. Exp. Clin. Endocrinol. Diabetes 2001, 109, 146-150. [CrossRef]

151. Brazionis, L.; Rowley, K.; Jenkins, A.J.; Itsiopoulos, C.; O’Dea, K. Plasminogen Activator Inhibitor-1 Activity in Type 2 Diabetes. Arterioscler. Thromb. Vasc. Biol. 2008, 28, 786-791. [CrossRef]

152. Rebalka, I.A.; Cao, A.W.; Raleigh, M.J.; Henriksbo, B.D.; Coleman, S.K.; Schertzer, J.D.; Hawke, T.J. Statin Therapy Negatively Impacts Skeletal Muscle Regeneration and Cutaneous Wound Repair in Type 1 Diabetic Mice. Front. Physiol. 2017, 8, 8. [CrossRef]

153. López-Otín, C.; Blasco, M.A.; Partridge, L.; Serrano, M.; Kroemer, G. The Hallmarks of Aging. Cell 2013, 153, 1194-1217. [CrossRef]

154. Yamamoto, K.; Takeshita, K.; Kojima, T.; Takamatsu, J.; Saito, H. Aging and plasminogen activator inhibitor-1 (PAI-1) regulation: Implication in the pathogenesis of thrombotic disorders in the elderly. Cardiovasc. Res. 2005, 66, 276-285. [CrossRef] [PubMed]

155. Eren, M.; Boe, A.E.; Klyachko, E.A.; Vaughan, D.E. Role of plasminogen activator inhibitor-1 in senescence and aging. Semin. Thromb. Hemost. 2014, 40, 645-651. [CrossRef] [PubMed] 
156. Miller, R.A.; Harrison, D.E.; Astle, C.M.; Bogue, M.A.; Brind, J.; Fernandez, E.; Flurkey, K.; Javors, M.; Ladiges, W.; Leeuwenburgh, C.; et al. Glycine supplementation extends lifespan of male and female mice. Aging Cell 2019, 18, e12953. [CrossRef] [PubMed]

157. Diéval, J.; Nguyen, G.; Gross, S.; Delobel, J.; Kruithof, E.K. A lifelong bleeding disorder associated with a deficiency of plasminogen activator inhibitor type 1. Blood 1991, 77, 528-532. [CrossRef] [PubMed]

158. Fay, W.P.; Parker, A.C.; Condrey, L.R.; Shapiro, A.D. Human Plasminogen Activator Inhibitor-1 (PAI-1) Deficiency: Characterization of a Large Kindred with a Null Mutation in the PAI-1 Gene. Blood 1997, 90, 204-208. [CrossRef]

159. Khan, S.S.; Shah, S.J.; Klyachko, E.; Baldridge, A.S.; Eren, M.; Place, A.T.; Aviv, A.; Puterman, E.; Lloyd-Jones, D.M.; Heiman, M.; et al. A null mutation in SERPINE1 protects against biological aging in humans. Sci. Adv. 2017, 3, eaao1617. [CrossRef]

160. Akhmedov, D.; Berdeaux, R. The effects of obesity on skeletal muscle regeneration. Front. Physiol. $2013,4$. [CrossRef]

161. Fu, X.; Zhu, M.; Zhang, S.; Foretz, M.; Viollet, B.; Du, M. Obesity Impairs Skeletal Muscle Regeneration through Inhibition of AMPK. Diabetes 2016, 65, 188-200. [CrossRef] [PubMed]

162. Fry, C.S.; Lee, J.D.; Mula, J.; Kirby, T.J.; Jackson, J.R.; Liu, F.; Yang, L.; Mendias, C.L.; Dupont-Versteegden, E.E.; McCarthy, J.J.; et al. Inducible depletion of satellite cells in adult, sedentary mice impairs muscle regenerative capacity without affecting sarcopenia. Nat. Med. 2015, 21, 76-80. [CrossRef]

163. Richard-Bulteau, H.; Serrurier, B.; Crassous, B.; Banzet, S.; Peinnequin, A.; Bigard, X.; Koulmann, N. Recovery of skeletal muscle mass after extensive injury: Positive effects of increased contractile activity. Am. J. Physiol. Cell Physiol. 2008, 294, C467-C476. [CrossRef] [PubMed]

164. Velazquez, E.M.; Mendoza, S.G.; Wang, P.; Glueck, C.J. Metformin therapy is associated with a decrease in plasma plasminogen activator inhibitor-1, lipoprotein(a), and immunoreactive insulin levels in patients with the polycystic ovary syndrome. Metabolism 1997, 46, 454-457. [CrossRef]

165. Anfosso, F.; Chomiki, N.; Alessi, M.C.; Vague, P.; Juhan-Vague, I. Plasminogen activator inhibitor-1 synthesis in the human hepatoma cell line Hep G2. Metformin inhibits the stimulating effect of insulin. J. Clin. Investig. 1993, 91, 2185-2193. [CrossRef] [PubMed]

166. Tan, B.K.; Adya, R.; Chen, J.; Farhatullah, S.; Heutling, D.; Mitchell, D.; Lehnert, H.; Randeva, H.S. Metformin decreases angiogenesis via NF- $\mathrm{BB}$ and Erk1/2/Erk5 pathways by increasing the antiangiogenic thrombospondin-1. Cardiovasc. Res. 2009, 83, 566-574. [CrossRef] [PubMed]

167. Langone, F.; Cannata, S.; Fuoco, C.; Lettieri Barbato, D.; Testa, S.; Nardozza, A.P.; Ciriolo, M.R.; Castagnoli, L.; Gargioli, C.; Cesareni, G. Metformin Protects Skeletal Muscle from Cardiotoxin Induced Degeneration. PLoS ONE 2014, 9, e114018. [CrossRef] [PubMed]

168. Zagotta, I.; Dimova, E.Y.; Funcke, J.-B.; Wabitsch, M.; Kietzmann, T.; Fischer-Posovszky, P. Resveratrol suppresses PAI-1 gene expression in a human in vitro model of inflamed adipose tissue. Oxidative Med. Cell. Longev. 2013, 2013, 793525. [CrossRef]

169. Ahn, J.; Lee, H.; Kim, S.; Ha, T. Resveratrol inhibits TNF-alpha-induced changes of adipokines in 3T3-L1 adipocytes. Biochem. Biophys. Res. Commun. 2007, 364, 972-977. [CrossRef]

170. Suenaga, F.; Hatsushika, K.; Takano, S.; Ando, T.; Ohnuma, Y.; Ogawa, H.; Nakao, A. A possible link between resveratrol and TGF- $\beta$ : Resveratrol induction of TGF- $\beta$ expression and signaling. FEBS Lett. 2008, 582, 586-590. [CrossRef]

171. Wang, Z.-H.; Ren, W.-Y.; Zhu, L.; Hu, L.-J. Plasminogen activator inhibitor-1 regulates LPS induced inflammation in rat macrophages through autophagy activation. Sci. World J. 2014, 2014, 189168. [CrossRef] [PubMed]

172. Gouda, M.M.; Prabhu, A.; Bhandary, Y.P. Curcumin alleviates IL-17A-mediated p53-PAI-1 expression in bleomycin-induced alveolar basal epithelial cells. J. Cell. Biochem. 2018, 119, 2222-2230. [CrossRef]

173. Hu, Y.; Liang, H.; Du, Y.; Zhu, Y.; Wang, X. Curcumin inhibits transforming growth factor-beta activity via inhibition of Smad signaling in HK-2 cells. Am. J. Nephrol. 2010, 31, 332-341. [CrossRef] [PubMed]

174. Shen, J.G.; Zhou, D.Y. Efficiency of Ginkgo biloba extract (EGb 761) in antioxidant protection against myocardial ischemia and reperfusion injury. Biochem. Mol. Biol. Int. 1995, 35, 125-134. [PubMed]

175. Leiherer, A.; Stoemmer, K.; Muendlein, A.; Saely, C.H.; Kinz, E.; Brandtner, E.M.; Fraunberger, P.; Drexel, H. Quercetin Impacts Expression of Metabolism- and Obesity-Associated Genes in SGBS Adipocytes. Nutrients 2016, 8, 282. [CrossRef] 
176. Gaedeke, J.; Noble, N.A.; Border, W.A. Curcumin blocks multiple sites of the TGF-beta signaling cascade in renal cells. Kidney Int. 2004, 66, 112-120. [CrossRef]

177. Han, T.; Zhang, G.; Yan, D.; Yang, H.; Ma, T.; Ye, Z. Modulation of plasminogen activator inhibitor-1 (PAI-1) by the naphthoquinone shikonin. Fitoterapia 2016, 113, 117-122. [CrossRef]

(C) 2020 by the authors. Licensee MDPI, Basel, Switzerland. This article is an open access article distributed under the terms and conditions of the Creative Commons Attribution (CC BY) license (http://creativecommons.org/licenses/by/4.0/). 